\title{
Down-Conversion Polymer Composite Coatings with Multipeak Absorption and Emission
}

\author{
Jun Fang 1,2,3, Wenting Liu 1,2,3, Wenying Zhou 1,2,3, Cheng Zhu 1,2,3,*, Yaru Ni 1,2,3,*, Liang Fang 1,2,3 \\ and Chunhua $\mathrm{Lu}$ 1,2,3,* \\ 1 State Key Laboratory of Materials-Oriented Chemical Engineering, College of Materials Science and \\ Engineering, Nanjing Tech University, Nanjing 210009, China; 201861203081@njtech.edu.cn (J.F.); \\ 201861103065@njtech.edu.cn (W.L.); zhouwenying77@163.com (W.Z.); lfang@njtech.edu.cn (L.F.) \\ 2 Jiangsu Collaborative Innovation Center for Advanced Inorganic Function Composites, \\ Nanjing Tech University, Nanjing 210009, China \\ 3 Jiangsu National Synergetic Innovation Center for Advanced Materials (SICAM), Nanjing Tech University, \\ Nanjing 210009, China \\ * Correspondence: zhucheng415@njtech.edu.cn (C.Z.); nyr@njtech.edu.cn (Y.N.); chhlu@njtech.edu.cn (C.L.)
}

check for

updates

Citation: Fang, J.; Liu, W.; Zhou, W.; Zhu, C.; Ni, Y.; Fang, L.; Lu, C. Down-Conversion Polymer Composite Coatings with Multipeak Absorption and Emission. Coatings 2021, 11, 282. https://doi.org/ $10.3390 /$ coatings 11030282

Received: 9 February 2021

Accepted: 24 February 2021

Published: 27 February 2021

Publisher's Note: MDPI stays neutral with regard to jurisdictional claims in published maps and institutional affiliations.

Copyright: (C) 2021 by the authors. Licensee MDPI, Basel, Switzerland. This article is an open access article distributed under the terms and conditions of the Creative Commons Attribution (CC BY) license (https:// creativecommons.org/licenses/by/ $4.0 /)$.

\begin{abstract}
Spectral adjustment is an effective method to increase light conversion efficiency of solar cells and to promote the growth of plants. Down-converter (DC) materials are considered to be one of the most effective methods of spectral modification. The focus of this work was to expand the spectral response range of down-conversion layers to achieve multipeak absorption and emission. $\mathrm{Sr}_{2} \mathrm{CaMoO}_{6}: \mathrm{Sm}, \mathrm{Na}$ and $\mathrm{YVO}_{4}: \mathrm{Bi}$,Eu, which have different excitation peaks in the UV-blue region and varied emission peaks in visible light regions, were prepared in this work. $\mathrm{Sr}_{2} \mathrm{CaMoO}_{6}: \mathrm{Sm}, \mathrm{Na}$ can effectively produce red light at $648 \mathrm{~nm}$ upon excitation at $408 \mathrm{~nm}$, while $\mathrm{YVO}_{4}: \mathrm{Bi}$,Eu can produce red light at $618 \mathrm{~nm}$ upon excitation at $365 \mathrm{~nm}$. Polymeric luminescent coatings with one single kind of phosphor were prepared separately before the two phosphors were mixed together in uniform polymer coatings. The two phosphors were also assembled in bilayer coatings with different concentrations. The results showed that high transmittances over $90 \%$ were achieved for the two composite coatings with the thickness of 20 and $30 \mu \mathrm{m}$. The increase in particle loadings from $1 \%$ o to $4 \%$ slightly decreased coating transmittance but increased luminescence intensity. The increase in the ratio of $\mathrm{Sr}_{2} \mathrm{CaMoO}_{6}: \mathrm{Sm}, \mathrm{Na}$ and $\mathrm{YVO}_{4}: \mathrm{Bi}$,Eu from 5/1 to 10/1 resulted in high transmittance of the DC coatings, independent of total filler loadings (3\% and $4 \%$ ) and coating thickness. The relative intensities of emission peaks can be adjusted conveniently by changing filler ratios. In addition, the transmittance and luminescent intensities of the coatings where the two phosphors were assembled in two layers were close to the uniform coatings, suggesting the negligible effect of UV light irradiation order. This work proved that the prepared coatings presented multipeak absorption and emission upon UV light excitation. These coatings can be expected to be applied in fields such as solar cells and agriculture greenhouses.
\end{abstract}

Keywords: $\mathrm{Sr}_{2} \mathrm{CaMoO}_{6}: \mathrm{Sm}, \mathrm{Na} ; \mathrm{YVO}_{4}: \mathrm{Bi}, \mathrm{Eu}$; polymeric luminescent coatings; down-conversion

\section{Introduction}

Spectral modification has been paid great attention in recent years because it has broad application prospects in many fields, including solar cells and agricultural greenhouses [1-4]. Taking solar cells as an example, spectral mismatch between uneven distribution of solar spectrum and spectral response of solar cells results in the limited conversion efficiency of solar cells [5,6]. In agriculture, shortwave photons that are not useful for plants can be converted into suitable light to promote their growth [7].

Down-conversion (DC) luminescent materials have become the focus of research as one of the spectral modification materials. [8-11]. Rare earth metals that have special electron layers and a rich number of energy level layers have been widely used in DC 
luminescent materials to improve solar energy efficiency or promote plant growth. [12-16]. It is worth emphasizing that the rare earth ions used in down-conversion materials have no obvious negative impact on the environment, and different rare earth ions can be selected according to different spectral control requirements. Among them, rare earth organic complexes are composed of lanthanide ions and organic ligands exhibit great luminescence properties and have high-efficiency absorption in ultraviolet (UV) region $[17,18]$. However, the photochemical stability of lanthanide complexes limits their application. The high photodegradation rate upon UV exposure is a drawback that seriously affects their luminescence performance [19-21]. Inorganic phosphors as other potential DC materials are expected to be applied in many fields. Sulfides [15], nitride [22,23], nitrogen oxides [24,25] of rare earth metals are commonly used as red phosphors. Most of them are stable in physical and chemical properties, which is a big advantage over rare earth organic complexes. However, the narrow absorption band and low absorption coefficient limit inorganic phosphors' further applications [26,27].

It is important to increase emission intensity and luminescent efficiency of inorganic phosphors [28]. Doping with different rare-earth ions can bring various luminescent effects [29]. The type and concentration of doping ions can be controlled to improve luminescence performance [30,31]. When rare-earth ion concentration in inorganic phosphors is higher than a critical valve, a quenching effect occurs and reduces the luminescent ability. In addition, defects in phosphor materials usually increase nonradiative transition channel and reduce quantum efficiency [32]. The reduction of defects in materials and nonradiative transition channels is a necessary approach to improve luminescent properties of phosphors [33,34]. Surface defects [35,36], atomic vacancy defects [37] and charge defects [38] usually exist in phosphors. Among them, charge defects often occur when trivalent rare earth ions are doped into the lattice to replace divalent metal ions. Such charge imbalance easily causes charge defects inside crystals. Several solutions are utilized to deal with this issue. For example, charge defects can be compensated in self-charge compensation by adding vacancies inside the lattice [39]. Another method is to replace divalent metal ions in crystal lattice with low-priced alkali metal ions $\left(\mathrm{Li}^{+}, \mathrm{Na}^{+}, \mathrm{K}^{+}\right)[40,41]$. The positive and negative charges in the lattice are mutually neutralized.

In addition to the increase in fluorescence intensity, the combination of two phosphors having different narrow absorption bands can be an effective method to achieve multipeak absorption and multipeak emission [42]. Molybdate and vanadate phosphors are candidate materials because of their different spectral characteristics and simple reaction conditions. Molybdate phosphors have low toxicity, low environmental pollution, good chemical stability, and good luminescent efficiency, which are potential candidates for red phosphors [43]. The $\mathrm{MoO}_{6}{ }^{6-}$ groups in molybdate phosphors can be excited by ultraviolet light in the range of 300-425 $\mathrm{nm}$. The excitation range can be further adjusted to blue light band via the addition of $\mathrm{Sm}^{3+}$ [44]. Vanadate phosphors are another functional inorganic material. Rare earth vanadate has high stability, good crystallinity and an effective absorption band in the ultraviolet region. Short-wavelength light energy can be converted into visible light by radiation due to the $\mathrm{V}-\mathrm{O}$ charge transfer of $\mathrm{VO}_{4}{ }^{3-}$. Excellent fluorescence properties can be achieved when rare earth ions occupy $\mathrm{Y}^{3+}$ sites in $\mathrm{YVO}_{4}$ [45].

To date, most reports focus on DC materials with one single organic of inorganic phosphors [46]. When two phosphors are used together to achieve multipeak absorption and emission, the effects of total loading content, weight ratio, coating thickness on transparency, and luminescence should be concerned. More importantly, whether the distribution of two phosphors in coatings affects DC properties is not reported.

In this work, we prepared $\mathrm{Sr}_{2} \mathrm{CaMoO}_{6}: \mathrm{Sm}, \mathrm{Na}$ and $\mathrm{YVO}_{4}: \mathrm{Bi}, \mathrm{Eu}$ that have different excitation peaks in UV-blue regions and various emission peaks in visible light regions before they were used together as phosphors in transparent luminescent polymer coatings to broaden the absorption of incident light and achieve an excellent emission spectrum. First, the luminescent properties of $\mathrm{Sr}_{2} \mathrm{CaMoO}_{6}: \mathrm{Sm}, \mathrm{Na}$ red molybdate phosphors were improved by charge compensation. How the structures and their associated properties 
varied with both amounts of $\mathrm{Sm}^{3+}$ and $\mathrm{Na}^{+}$ions were then investigated. The effect of $\mathrm{Na}^{+}$ ions was studied subsequently at a constant $\mathrm{Sm}^{3+}$ ratio. The luminescent properties of $\mathrm{YVO}_{4}: \mathrm{Bi}$,Eu red phosphors were improved next by changing the concentration of rareearth ions. The phosphor particles were further refined to improve their dispersion in a polymer matrix and to maintain transparency. Subsequently, luminescent polymeric coatings with one single kind of phosphors were prepared separately before the two phosphors were combined in uniform polymer coatings. For the ultraviolet light excitation sequence was concerned, the two phosphors were assembled in bilayer coatings with different concentrations. The transparency and luminescent spectra were investigated in detail.

\section{Experimental}

\subsection{Materials and Synthesis of $\mathrm{Sr}_{2} \mathrm{CaMoO}_{6}: \mathrm{Sm}, \mathrm{Na}$ and $\mathrm{YVO}_{4}: \mathrm{Bi}, \mathrm{Eu}$}

All the chemicals were commercially available. $\mathrm{SrCO}_{3}(99 \%), \mathrm{CaCO}_{3}(99 \%), \mathrm{MoO}_{3}$ (99.9\%), $\mathrm{Sm}_{2} \mathrm{O}_{3}(99.9 \%)$ and $\mathrm{Na}_{2} \mathrm{CO}_{3}$ (A.R. grade) were obtained from Sinopharm Chemical Reagent Co., Ltd. $\mathrm{Y}_{2} \mathrm{O}_{3}(99 \%), \mathrm{NH}_{4} \mathrm{VO}_{3}(99 \%), \mathrm{Eu}_{2} \mathrm{O}_{3}(99.9 \%)$ and $\mathrm{Bi}_{2} \mathrm{O}_{3}(99.9 \%)$ were all purchased from Aladdin Reagent Co., Ltd. Poly (Shanghai, China) (ethylene terephthalateco-1,4-cylclohexylenedimethylene terephthalate) (PETG) was provided by Eastman Kodak Chemical Company (Kingsport, TN, USA). 1,1,2,2,-tetrachlor-ethane $\left(\mathrm{C}_{2} \mathrm{H}_{2} \mathrm{Cl}_{4}\right)$ was purchased from Sinopharm Chemical Reagent Co., Ltd. (Shanghai, China).

$\mathrm{Sr}_{2} \mathrm{CaMoO}_{6}: \mathrm{Sm}, \mathrm{Na}$ phosphors were synthesized by a high-temperature solid-state method with a tiny modification [47]. According to certain molar ratios, $\mathrm{SrCO}_{3}, \mathrm{CaCO}_{3}$, $\mathrm{MoO}_{3}, \mathrm{Sm}_{2} \mathrm{O}_{3}$ and $\mathrm{Na}_{2} \mathrm{CO}_{3}$ were ground in a mortar for $40 \mathrm{~min}$ and heated in a muffle furnace at $600{ }^{\circ} \mathrm{C}$ for $3 \mathrm{~h}$. The calcined powder was ground in a mortar for another $30 \mathrm{~min}$ and further treated at $900{ }^{\circ} \mathrm{C}$ for $3 \mathrm{~h}$. Finally, the powder was placed in a high temperature electric furnace and heat-treated at $1200{ }^{\circ} \mathrm{C}$ for $12 \mathrm{~h}$. The name and the corresponding molar ratios of the examined samples are listed in Table 1.

Table 1. The names and corresponding molar ratios of raw materials for the examined $\mathrm{Sr}_{2} \mathrm{CaMoO}_{6}: \mathrm{Sm}, \mathrm{Na}$ phosphors samples.

\begin{tabular}{|c|c|c|c|c|c|}
\hline Name & $\mathrm{SrCO}_{3}$ & $\mathrm{CaCO}_{3}$ & $\mathrm{MoO}_{3}$ & $\mathrm{Sm}_{2} \mathrm{O}_{3}$ & $\mathrm{Na}_{2} \mathrm{CO}_{3}$ \\
\hline $\mathrm{Sm} 20 \mathrm{Na} 00$ & 1.980 & 1 & 1 & 0.0100 & 0.0000 \\
\hline Sm10Na10 & 1.980 & 1 & 1 & 0.0050 & 0.0050 \\
\hline Sm15Na15 & 1.970 & 1 & 1 & 0.0075 & 0.0075 \\
\hline Sm20Na20 & 1.960 & 1 & 1 & 0.0100 & 0.0100 \\
\hline Sm25Na25 & 1.950 & 1 & 1 & 0.0125 & 0.0125 \\
\hline Sm30Na30 & 1.940 & 1 & 1 & 0.0150 & 0.0150 \\
\hline $\mathrm{Sm} 25 \mathrm{Na} 00$ & 1.975 & 1 & 1 & 0.0125 & 0.0000 \\
\hline Sm25Na15 & 1.960 & 1 & 1 & 0.0125 & 0.0075 \\
\hline Sm25Na20 & 1.955 & 1 & 1 & 0.0125 & 0.0100 \\
\hline Sm25Na30 & 1.945 & 1 & 1 & 0.0125 & 0.0150 \\
\hline Sm25Na35 & 1.940 & 1 & 1 & 0.0125 & 0.0175 \\
\hline
\end{tabular}

$\mathrm{YVO}_{4}: 0.04 \mathrm{Bi}^{3+}, \mathrm{Eu}^{3+}$ phosphors were synthesized via a solid-state reaction method. According to certain molar ratios, $\mathrm{Y}_{2} \mathrm{O}_{3}, \mathrm{NH}_{4} \mathrm{VO}_{3}, \mathrm{Eu}_{2} \mathrm{O}_{3}, \mathrm{Bi}_{2} \mathrm{O}_{3}$ were mixed and ground in an agate mortar with a pestle. Subsequently, the well-ground mixture was calcined at $800{ }^{\circ} \mathrm{C}$ for $4 \mathrm{~h}$ in an air atmosphere. The name and the corresponding molar ratios of the examined samples are listed in Table 2.

The obtained nanophosphors were ground for another $48 \mathrm{~h}$ and used for a further measurement. 
Table 2. The names and corresponding molar ratios of raw materials for the examined $\mathrm{YVO}_{4}: 0.04 \mathrm{Bi}^{3+}$, $\mathrm{Eu}^{3+}$ samples.

\begin{tabular}{ccccc}
\hline Name & $\mathbf{Y}_{\mathbf{2}} \mathbf{O}_{\mathbf{3}}$ & $\mathbf{N H}_{\mathbf{4}} \mathbf{V O}_{\mathbf{3}}$ & $\mathbf{B i}_{\mathbf{2}} \mathbf{O}_{\mathbf{3}}$ & $\mathbf{E u}_{\mathbf{2}} \mathbf{O}_{\mathbf{3}}$ \\
\hline $\mathrm{Eu01}$ & 0.475 & 1 & 0.02 & 0.005 \\
$\mathrm{Eu02}$ & 0.470 & 1 & 0.02 & 0.010 \\
$\mathrm{Eu03}$ & 0.465 & 1 & 0.02 & 0.015 \\
$\mathrm{Eu04}$ & 0.460 & 1 & 0.02 & 0.020 \\
$\mathrm{Eu05}$ & 0.455 & 1 & 0.02 & 0.025 \\
\hline
\end{tabular}

\subsection{Preparations of the Polymeric Luminescent Coatings}

The luminescent polymeric coatings with single phosphors were prepared as follows. The phosphor was dispersed ultrasonically in $100 \mathrm{~mL} \mathrm{C}_{2} \mathrm{H}_{2} \mathrm{Cl}_{4}$ before $20 \mathrm{~g}$ of PETG were added. The mixture was stirred at $80^{\circ} \mathrm{C}$ until PETG was completely dissolved. The mixed solutions containing different phosphor concentrations (1-4\%o) were obtained. Then, a spray coating method was used for preparing the coatings on quartz glass. The thickness was controlled to be 20 or $30 \mu \mathrm{m}$, respectively.

The single-layer luminescent polymeric coatings that were directly mixed with two phosphors were prepared as well. The weight ratios of $\mathrm{YVO}_{4}: \mathrm{Bi}, \mathrm{Eu}$ and $\mathrm{Sr}_{2} \mathrm{CaMoO}_{6}: \mathrm{Sm}, \mathrm{Na}$ were 1:5 and 1:10, respectively. The total powder contents were $3 \%$ or $4 \%$. The following preparation of coatings was the same as mentioned above.

Double-layer coatings were prepared, and the total powder contents were also $3 \%$ or $4 \%$. The coating thickness was $30 \mu \mathrm{m}$. The two phosphors were distributed in different layers. The names of the polymeric luminescent coatings and corresponding parameters are listed in Tables 3-5.

Table 3. The name of the polymeric luminescent coatings with single phosphors.

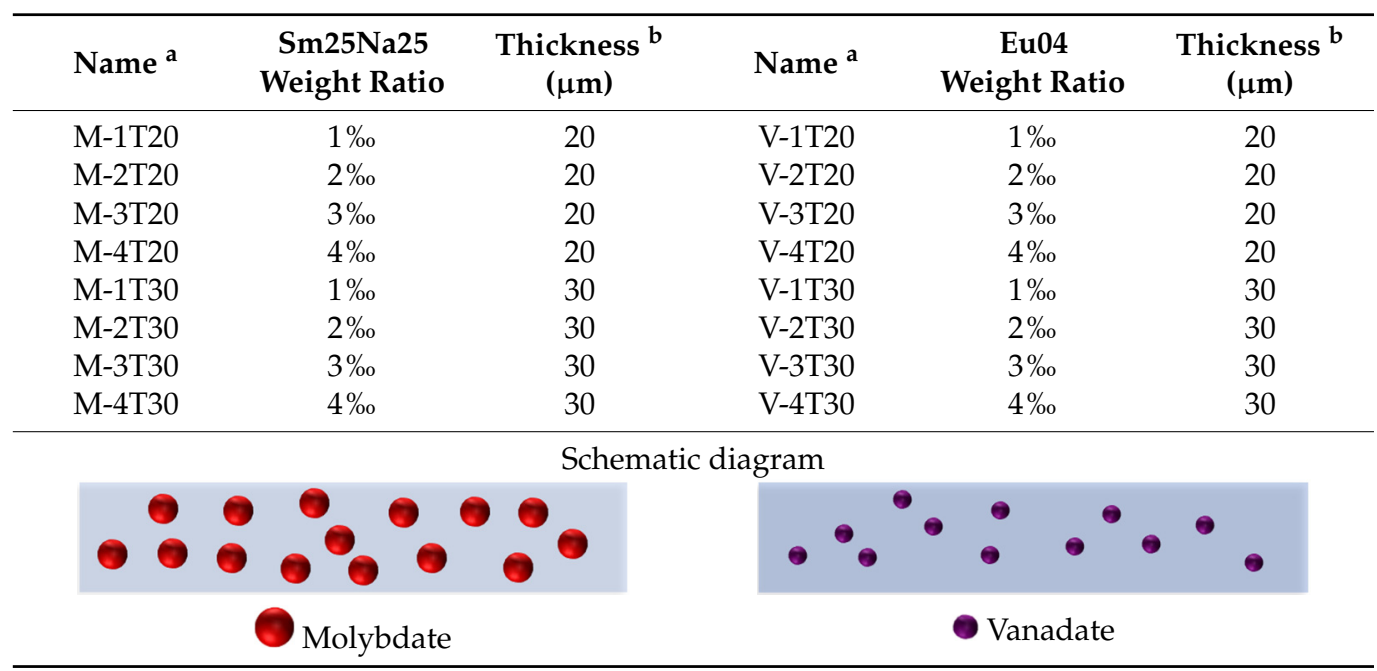

a: $\mathrm{M}$ and $\mathrm{V}$ stand for molybdate and vanadate phosphors, respectively. $\mathrm{T}$ stands for thickness in $\mu \mathrm{m}$. ${ }^{\mathrm{b}}$ : The uncertainty of coating thickness was $\pm 1 \mu \mathrm{m}$.

\subsection{Characterizations and Calculation}

An X-ray diffractometer (ARLX'TRAX-3KW, American Thermoelectric Company, Pennsylvania, Massachusetts, America) was used to characterize the phase, crystal structure, and unit cell parameters of the prepared samples at a scan rate of $10^{\circ} \mathrm{min}^{-1}$ and a scan range of $10-80^{\circ}$. A scanning electron microscope (JSM-IT200, Tokyo, Japan) was used to observe the surface topography of the sample. Agilent Cary 5000 UV-Vis-NIR spectrophotometer was used for spectral testing of the prepared samples. Reflectance test conditions were set to a slit width of $2 \mathrm{~nm}$, a scan speed of medium speed and a test wavelength of 200-1000 nm. The fluorescence performance was tested at a certain excita- 
tion wavelength by an FL3-221 fluorescence spectrophotometer from HORIBA JobinYvon, France. The particle size distribution of phosphors was obtained by a laser diffraction particle size analyzer (Mastersizer 2000, Malvern Instruments Ltd., Worcestershire, UK).

Table 4. The name of the polymeric luminescent coatings that were directly mixed with two phosphors.

\begin{tabular}{cccc}
\hline Name $^{\mathbf{a}}$ & $\begin{array}{c}\text { Ratio } \\
(\text { Eu04:Sm25Na25) }\end{array}$ & $\begin{array}{c}\text { Total Powder Weight } \\
\text { Ratio }\end{array}$ & Thickness $^{\mathbf{b}(\boldsymbol{\mu m})}$ \\
\hline Z3R15T20 & $1: 5$ & $3 \%$ & 20 \\
Z3R15T30 & $1: 5$ & $3 \%$ & 30 \\
Z3R110T20 & $1: 10$ & $3 \%$ & 20 \\
Z3R110T30 & $1: 10$ & $3 \%$ o & 30 \\
Z4R15T20 & $1: 5$ & $4 \%$ & 20 \\
Z4R15T30 & $1: 5$ & $4 \%$ & 30 \\
Z4R110T20 & $1: 10$ & $4 \% o$ & 20 \\
Z4R110T30 & $1: 10$ & $4 \%$ & 30 \\
\hline
\end{tabular}

\section{Schematic diagram}

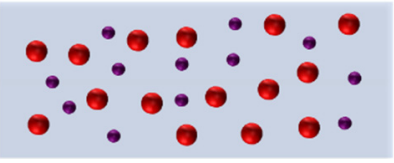

a: $\mathrm{Z}$ means that vanadate and molybdate phosphors were mixed in polymer coatings. $\mathrm{R}$ and $\mathrm{T}$ stand for their weight ratio and coating thickness, respectively. ${ }^{\mathrm{b}}$ : The uncertainty of coating thickness was $\pm 1 \mu \mathrm{m}$.

Table 5. The name of the double-layer polymeric luminescent coatings with different phosphor weight ratios.

\begin{tabular}{ccccc}
\hline Name $^{\mathbf{a}}$ & $\begin{array}{c}\text { Total Powder } \\
\text { Weight Ratio }\end{array}$ & $\begin{array}{c}\text { Ratio } \\
\text { (Eu04:Sm25Na25) }\end{array}$ & Upper Layer & Lower Layer \\
\hline Bi3R15SE & $3 \%$ & $1: 5$ & Sm25Na25 & Eu04 \\
Bi3R110SE & $3 \%$ & $1: 10$ & Sm25Na25 & Eu04 \\
Bi4R15SE & $4 \%$ & $1: 5$ & Sm25Na25 & Eu04 \\
Bi4R110SE & $4 \%$ & $1: 10$ & Sm25Na25 & Eu04 \\
Bi3R15ES & $3 \%$ & $1: 5$ & Eu04 & Sm25Na25 \\
Bi3R110ES & $3 \%$ & $1: 10$ & Eu04 & Sm25Na25 \\
Bi4R15ES & $4 \%$ & $1: 5$ & Eu04 & Sm25Na25 \\
Bi4R110ES & $4 \%$ & $1: 10$ & Eu04 & Sm25Na25 \\
\hline
\end{tabular}

Schematic diagram of Sm25Na25 in the upper layer

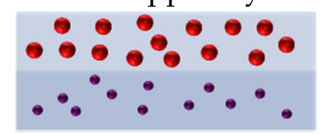

Schematic diagram of Eu04 in the upper layer

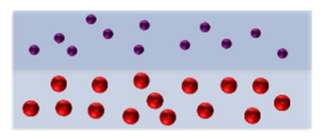

$\bar{a}$ : Bi means that vanadate and molybdate phosphors were mixed separately in bilayered polymer coatings. $\mathrm{R}$ stands for their weight ratio. The whole coating thickness was $30 \pm 1 \mu \mathrm{m}$.

The calculation of the electronic structures of $\mathrm{YVO}_{4}: \mathrm{Bi}$ and $\mathrm{Sr}_{2} \mathrm{CaMoO}_{6}: \mathrm{Sm}, \mathrm{Na}$ was performed with the density functional theory (DFT) using the CASTEP code, in which the electron-ion interactions were described by pseudopotential method and electronic wave functions are represented by means of a plane-wave basis set. The first step was to use crystallographic data to construct a $\mathrm{YVO}_{4}$ unit cell, in which one $\mathrm{Y}$ ion is replaced by a Bi ion. Generalized gradient approximation (GGA) by the Perdew, Burke and Ernzerhof (PBE) formulation was chosen to optimize the crystal structure. The second step was to calculate the band structure and density of states of $\mathrm{YVO}_{4}$ and $\mathrm{YVO}_{4} ; \mathrm{Bi}$. The kinetic cutoff energy was $571 \mathrm{eV}$ and Brillouin zone integration was represented using the K-point sampling scheme of $5 \times 6 \times 6$ Monkhorst-Pack grid. Ultrasoft pseudopotentials were used 
to approximate the core electrons. The calculation method and setting parameters of the $\mathrm{Sr}_{2} \mathrm{CaMoO}_{6}: \mathrm{Sm}$ and $\mathrm{Sr}_{2} \mathrm{CaMoO}_{6}: \mathrm{Sm}, \mathrm{Na}$ are the same as those of $\mathrm{YVO}_{4}: \mathrm{Bi}$.

\section{Results and Discussion}

\section{1. $\mathrm{Sr}_{2} \mathrm{CaMoO}_{6}: \mathrm{Sm}, \mathrm{Na}$ Phosphors}

\subsubsection{Effect of Doping Amounts of $\mathrm{Sm}^{3+}$ and $\mathrm{Na}^{+}$}

The effect of $\mathrm{Sm}^{3+}$ and $\mathrm{Na}^{+}$doping was studied first. The XRD patterns of the obtained phosphor samples of $\mathrm{Sr}_{2} \mathrm{CaMoO}_{6}: \mathrm{Sm}, \mathrm{Na}$ and the JCPDS card No: 48-799 are shown in Figure 1a. Main diffraction peaks at $30.8^{\circ}$ and $44.1^{\circ}$ of the phosphors were observed, which match with the JCPDS standard card peaks of $\alpha-\mathrm{Sr}_{2} \mathrm{CaMoO}_{6}$ with an orthogonal crystal system. Because the radius of the doped $\mathrm{Sm}^{3+}$ and $\mathrm{Na}^{+}$ions are close to the radius of $\mathrm{Sr}^{2+}$ ions, they can occupy the lattice sites of $\mathrm{Sr}^{2+}$ at random. The diffraction peaks in Sm10Na10$\mathrm{Sm} 30 \mathrm{Na} 30$ doped with $\mathrm{Na}^{+}$were not changed compared with those in Sm25Na00. It can be argued that $\mathrm{Sm}^{3+}$ and $\mathrm{Na}^{+}$may enter the matrix lattice of $\mathrm{Sr}_{2} \mathrm{CaMoO}_{6}$ effectively.
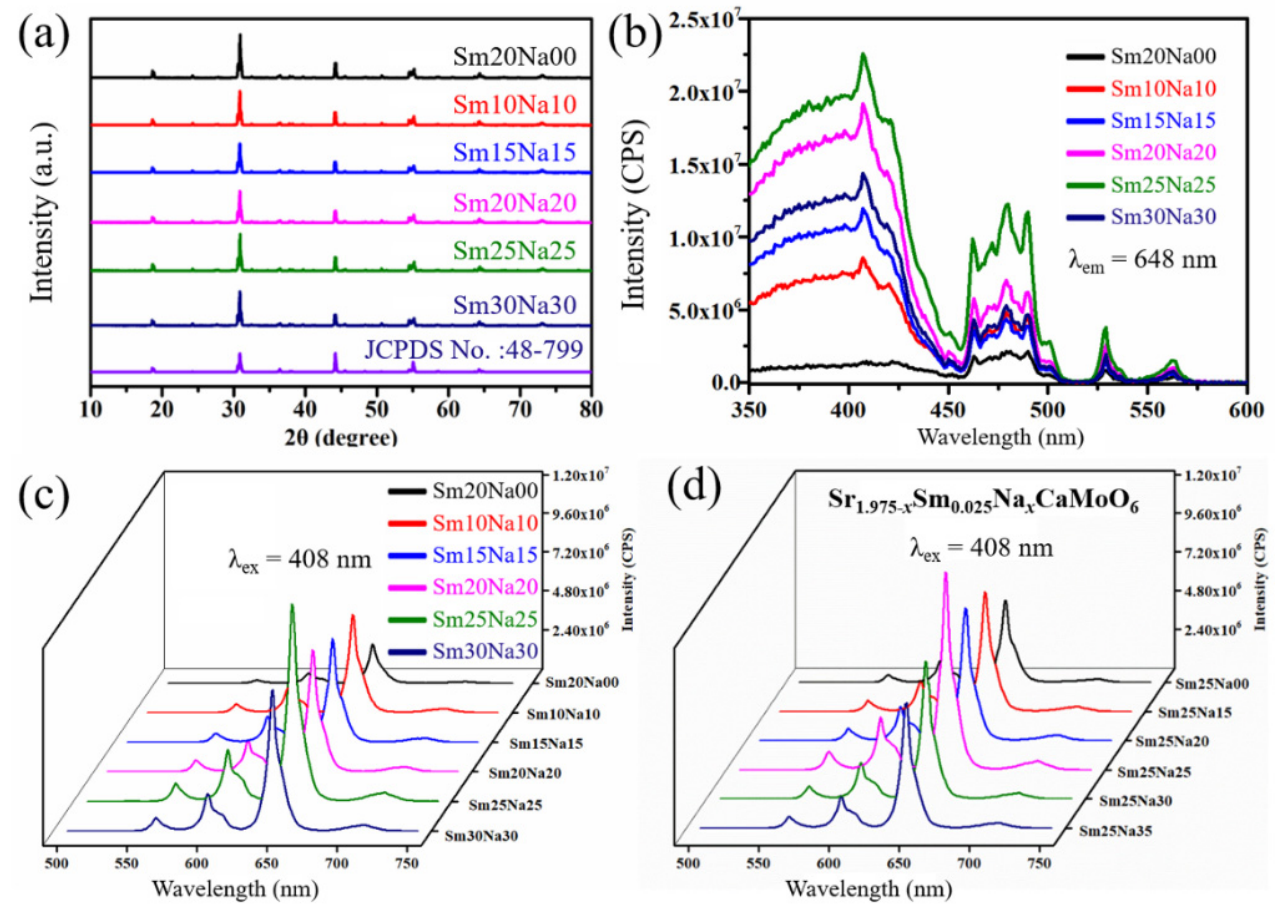

Figure 1. (a) XRD patterns of the $\mathrm{Sr}_{2} \mathrm{CaMoO}_{6}: \mathrm{Sm}, \mathrm{Na}(\mathrm{Sm} 20 \mathrm{Na} 00-\mathrm{Sm} 30 \mathrm{Na} 30)$. (b) Excitation spectra $\left(\lambda_{\mathrm{em}}=648 \mathrm{~nm}\right)$ of the $\mathrm{Sr}_{2} \mathrm{CaMoO}_{6}: \mathrm{Sm}, \mathrm{Na}$ samples. (c) Fluorescence emission spectra of $\mathrm{Sr}_{2} \mathrm{CaMoO}_{6}: \mathrm{Sm}, \mathrm{Na}$ samples $\left(\lambda_{\mathrm{ex}}=408 \mathrm{~nm}\right)$. (d) Fluorescence emission spectra of $\mathrm{Sr}_{1.975-x} \mathrm{CaMoO}_{6}: 0.025 \mathrm{Sm}, x \mathrm{Na}$ series samples. $\left(\lambda_{\mathrm{em}}\right.$ stands for the emission wavelength and $\lambda_{\mathrm{ex}}$ stands for the excitation wavelength.).

The excitation spectra (Figure 1b) were composed of two parts in the UV-blue region. The wide peak at $350-450 \mathrm{~nm}$ originated from the electron transition of $\mathrm{O}^{2-} \rightarrow \mathrm{Mo}^{6+}$ charge transfer band in the $\mathrm{MoO}_{6}{ }^{6-}$ matrix. The other part of narrow-band excitation peaks was located at $450-500,530$, and $565 \mathrm{~nm}$ due to the characteristic transition of $\mathrm{Sm}^{3+}$ from ground state ${ }^{6} \mathrm{H}_{5 / 2}$ to various high-energy excited states. The luminescence intensities at the highest excitation peak $(408 \mathrm{~nm})$ are 14 and 5.2 times higher than those of the phosphors without charge compensation ion $\mathrm{Na}^{+}$when the doping amounts of $\mathrm{Sm}^{3+}$ and $\mathrm{Na}^{+}$were $2.5 \mathrm{~mol} \%$ and $1 \mathrm{~mol} \%$, respectively. The luminescence intensities at the excitation peak of $465 \mathrm{~nm}$ are 5 and 1.8 times higher than those of the phosphors without charge compensation ion $\mathrm{Na}$ when the doping amounts of $\mathrm{Sm}^{3+}$ and $\mathrm{Na}^{+}$were $2.5 \mathrm{~mol} \%$ and $1 \mathrm{~mol} \%$, respectively. The fluorescence emission spectra of $\mathrm{Sr}_{2} \mathrm{CaMoO}_{6}: \mathrm{Sm}, \mathrm{Na}$ samples are shown in Figure 1c. The emission spectra excited by $408 \mathrm{~nm}$ are mainly the characteristic 
peaks of $\mathrm{Sm}^{3+}$. The strong emission peak at $648 \mathrm{~nm}$ and the relatively weak emission peaks at 562,600 and $712 \mathrm{~nm}$ were generated by ${ }^{4} \mathrm{G}_{5 / 2} \rightarrow{ }^{6} \mathrm{H}_{9 / 2},{ }^{4} \mathrm{G}_{5 / 2} \rightarrow{ }^{6} \mathrm{H}_{5 / 2},{ }^{4} \mathrm{G}_{5 / 2} \rightarrow{ }^{6} \mathrm{H}_{7 / 2}$, and ${ }^{4} \mathrm{G}_{5 / 2} \rightarrow{ }^{6} \mathrm{H}_{11 / 2}$ energy level transitions, respectively. The fluorescence intensity of Sm25Na25 reached the highest value, which is five times higher than that of the undoped sample. This result is also consistent with the excitation spectrum (Figure 1b).

To verify whether the low-cost alkali metal $\mathrm{Na}^{+}$had the charge compensation effect, the phosphors of $\mathrm{Sr}_{1.975-x} \mathrm{CaMoO}_{6}: 0.025 \mathrm{Sm}, x \mathrm{Na}$ series were synthesized by only changing the doping amount of $\mathrm{Na}^{+}$(Table 1). The fluorescence properties of $\mathrm{Sr}_{1.975-x} \mathrm{CaMoO}_{6}: 0.025 \mathrm{Sm}, x \mathrm{Na}$ samples prepared by high-temperature solid phase are shown in Figure 1d. The emission intensity was enhanced by increasing the $\mathrm{Na}^{+}$content of the samples, when they were excited by the light at $408 \mathrm{~nm}$. By further increasing $\mathrm{Na}^{+}$concentration, the excessive charge caused by the compensator brought lattice defects due to charge imbalance in the lattice, decreasing the internal quantum efficiency. The maximum intensity, thus, was obtained until the doping amounts of $\mathrm{Na}^{+}$and $\mathrm{Sm}^{3+}$ were equal in Sm25Na25.

\subsubsection{Band Structure and Density of States}

For the purpose of clarifying the role of $\mathrm{Na}^{+}$on the band structure in the phosphor host, we calculated the band structure and total density of states (DOS) of the Sm25Na00 and Sm25Na25. The calculated electronic band structures of the phosphors on the basis of DFT calculations are shown in Figure 2. It can be observed that the energy structures of the two samples are similar. The lowest energy of conduction bands (CBs) was located at $S$ site of Brillouin zone and the highest point of valence bands (VBs) was located at $G$ point. Hence, the phosphors were indirect bandgap materials. The gap between the lowest energy of the CBs and the highest energy of the VBs in Sm25Na25 was $2.063 \mathrm{eV}$, which is $0.018 \mathrm{eV}$ smaller than that of the optical band gap of Sm25Na00. The reason for the small difference in optical band gap between the two samples is the low doping amount of $\mathrm{Na}^{+}$. The DOS of the phosphors is shown in Figure 2. After doping with $\mathrm{Na}^{+}$, the main peak in density of states in the Sm25Na25 were improved compared with the nondoped sample, suggesting that the free electrons were increased. The above calculation results also agree with the experimental results, i.e., the addition of $\mathrm{Na}^{+}$enhanced the luminescence properties of the phosphors.
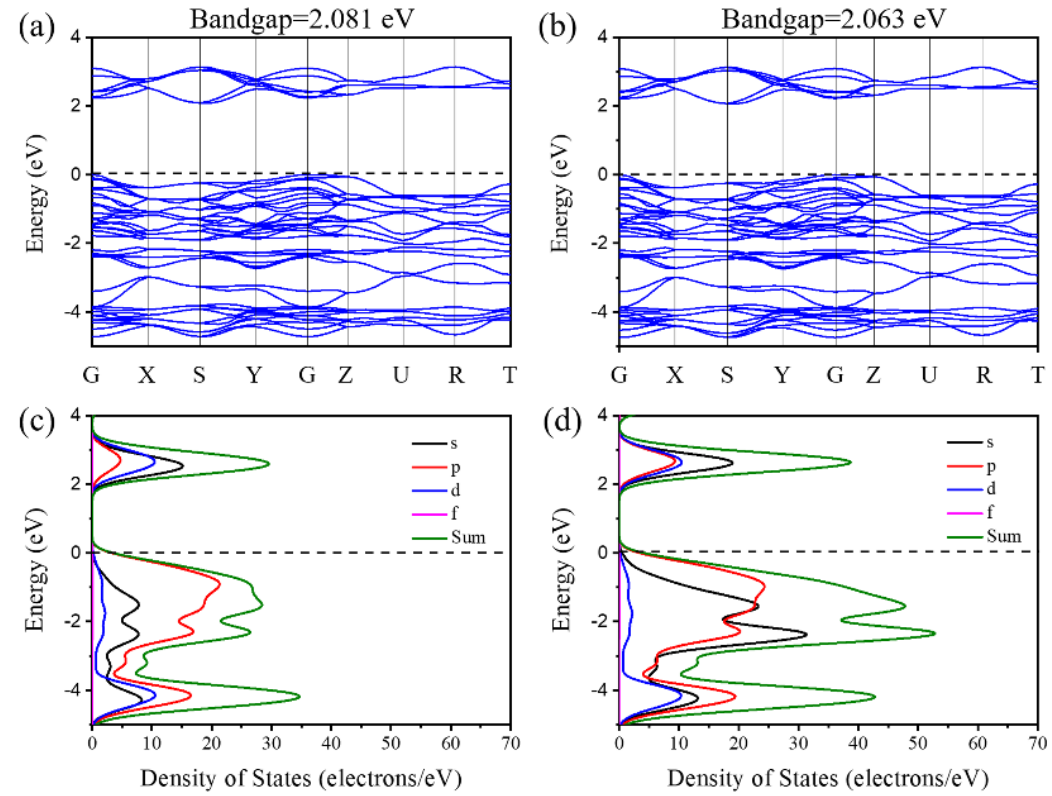

Figure 2. The calculated energy band structure of $\mathrm{Sm} 25 \mathrm{Na} 00$ (a) and $\mathrm{Sm} 25 \mathrm{Na} 25$ (b). Density of states of Sm25Na00 (c) and Sm25Na25 (d) near the Fermi energy level (the Fermi energy is the zero of the energy scale). 


\section{2. $\mathrm{YVO}_{4}: \mathrm{Bi}, \mathrm{Eu}$}

\subsubsection{Effect of Amounts of $\mathrm{Eu}^{3+}$}

The XRD patterns of the samples with different $\mathrm{Eu}^{3+}$ doping concentrations and the JCPDS card No: 17-0341 are shown in Figure 3a. These samples are completely consistent with tetragonal $\mathrm{YVO}_{4}$. The doping of Eu ${ }^{3+}$ ions did not cause any significant changes in the crystal structure. The diffraction pattern reveals that $\mathrm{Eu}^{3+}$ ions were substituted in the $\mathrm{Y}^{3+}$ sites of $\mathrm{YVO}_{4}$ host. In addition, impurity peaks were negligibly detected within the experimental range and no shift in peaks for Eu ${ }^{3+}$ doped $\mathrm{YVO}_{4}$ was found, indicating that the samples are mainly in the pure tetragonal phase.
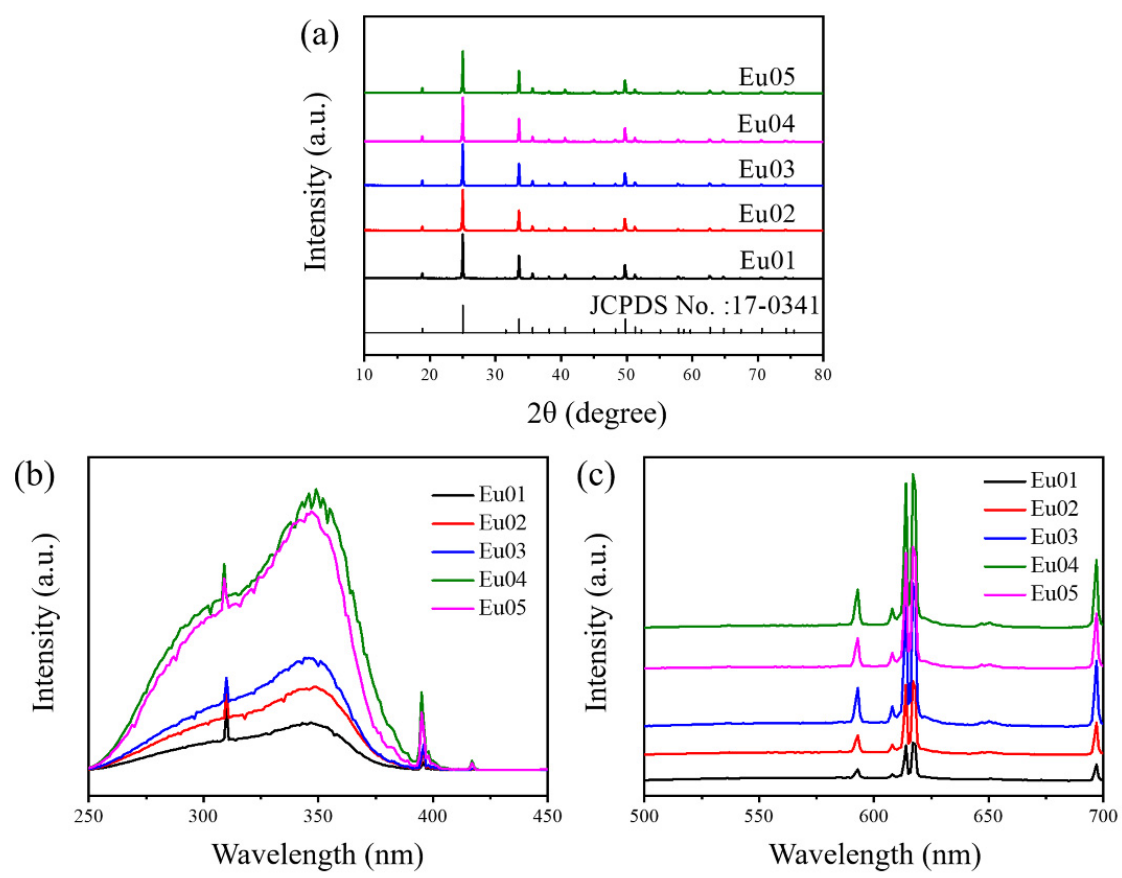

Figure 3. (a) XRD patterns of $\mathrm{YVO}_{4}: \mathrm{Bi}$,Eu. (b) Excitation $\left(\lambda_{\mathrm{em}}=618 \mathrm{~nm}\right)$ spectra of $\mathrm{YVO}_{4}: \mathrm{Bi}$,Eu. (c) Emission $\left(\lambda_{\mathrm{ex}}=365 \mathrm{~nm}\right)$ spectra of $\mathrm{YVO}_{4}: \mathrm{Bi}$,Eu.

To obtain the sample with optimal luminescence properties, the excitation and emission spectra of samples were characterized. As shown in Figure $3 b$, a broad excitation band appeared in the range of $250-400 \mathrm{~nm}$ that corresponds to the charge transfer from excited ligands to the central vanadium atom inside $\mathrm{VO}_{4}{ }^{3-}$ groups. A weak peak at $395 \mathrm{~nm}$ originated from the ${ }^{7} \mathrm{~F}_{0}-{ }^{5} \mathrm{~L}_{6}$ transitions within the $4 \mathrm{f}^{6}$ configuration of the $\mathrm{Eu}^{3+}$ ions. The intensity reached the highest when the $\mathrm{Eu}^{3+}$ concentration was $4 \mathrm{~mol} \%$. In the emission spectra (Figure 3c), the weak emission at $593 \mathrm{~nm}$ and strong emission at $618 \mathrm{~nm}$ correspond to the ${ }^{5} \mathrm{D}_{1}-{ }^{7} \mathrm{~F}_{1}$ and ${ }^{5} \mathrm{D}_{0}-{ }^{7} \mathrm{~F}_{\mathrm{J}}(\mathrm{J}=0-4)$ transition of $\mathrm{Eu}^{3+}$, respectively. The emission intensity gradually increased when the concentration of $\mathrm{Eu}^{3+}$ varied from 1 to $4 \mathrm{~mol} \%$. The intensity reached the highest level at $4 \mathrm{~mol} \%$, and then the intensity decreased with the further increased concentration due to the concentration quenching effect. Therefore, the sample Eu04 was used for further study.

\subsubsection{Band Structure and Density of States}

To clarify the role of $\mathrm{Bi}$ on the band structure in $\mathrm{YVO}_{4}: \mathrm{Bi}$,Eu host, band structure and partial density of states (PDOS) of atoms were calculated to explain chemical bonding properties and origin of CT transitions of $\mathrm{YVO}_{4}: \mathrm{Bi}$, Eu. The DFT method was also used to calculate the influence of the replacement of $\mathrm{Y}$ with $\mathrm{Bi}$ in the $\mathrm{YVO}_{4}: \mathrm{Bi}$,Eu host. A unit cell with 20 atoms was used, and the cutoff energy was $571 \mathrm{eV}$. One $\mathrm{Y}$ atom is substituted by $\mathrm{Bi}$. Due to the large and expensive computation, the cases with the Bi percentage were not simulated. Figure 4 shows the calculated band structure along the high symmetry points 
of the first Brillouin zone for $\mathrm{YVO}_{4}$ :Bi. The lowest energy of conduction bands (CBs) was localized at $\mathrm{G}$ point, while the highest point of the valence bands (VBs) was in $\mathrm{P}$ point. Hence, $\mathrm{YVO}_{4}: \mathrm{Bi}$ is an indirect bandgap material, and the gap between the lowest energy of the CBs, and the highest energy of the VBs is about $2.846 \mathrm{eV}$. DFT is a ground state theory, but band gap belongs to the properties of excited states. Therefore, the difference from generalized gradient approximation (GGA) in DFT calculations generally underestimates the band gap of insulators and semiconductors.

(a)
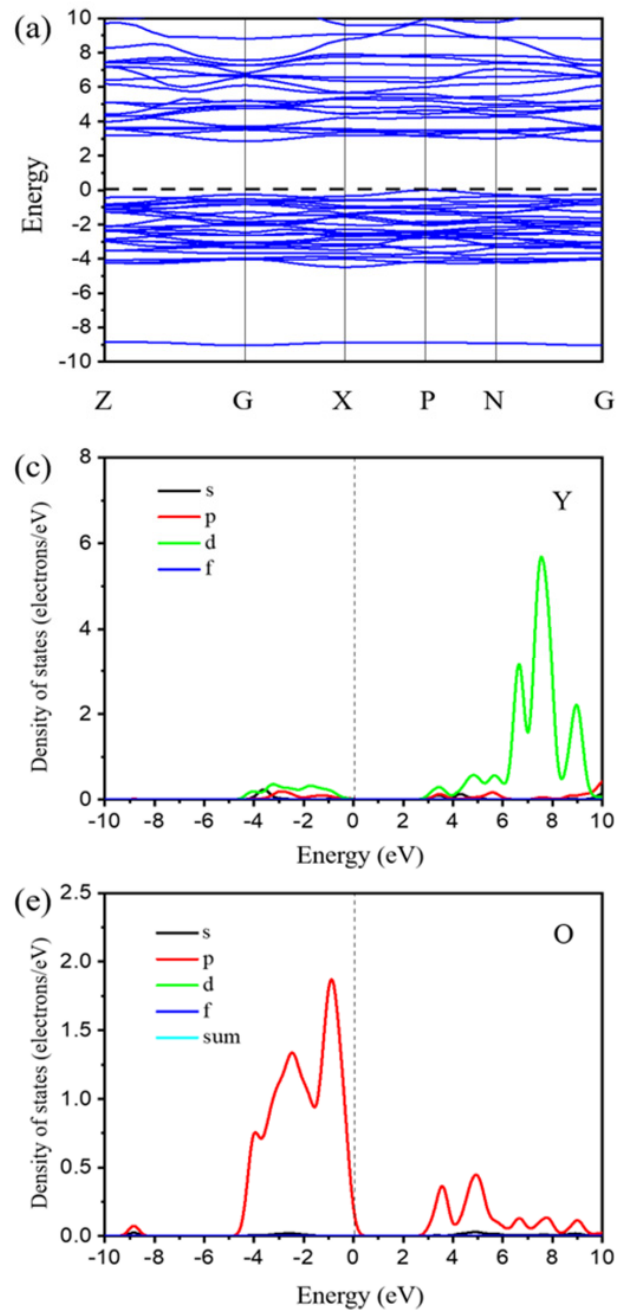
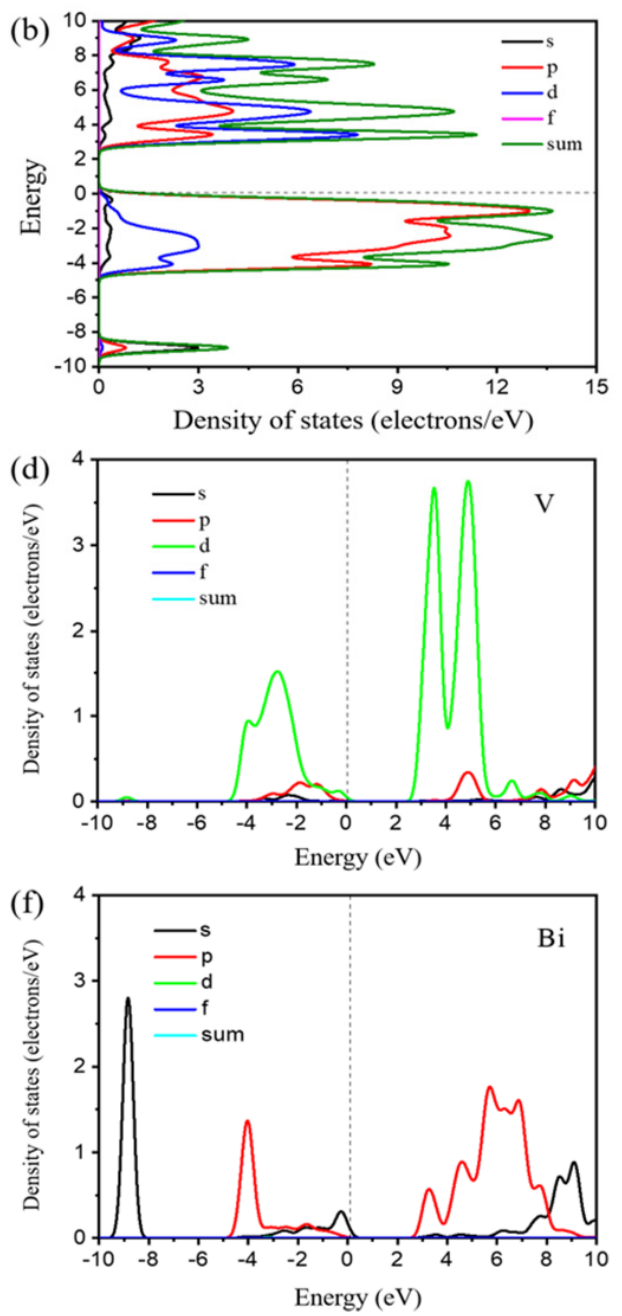

Figure 4. The calculated energy band structure and density of states of $\mathrm{YVO}_{4}: \mathrm{Bi}, \mathrm{Eu}(\mathbf{a}, \mathbf{b})$. Partial densities of states of $\mathrm{YVO}_{4}: \mathrm{Bi}$,Eu (c-f) near the Fermi energy level (the Fermi energy is the zero of the energy scale).

The partial density of states (PDOS) of $\mathrm{YVO}_{4}$ : $\mathrm{Bi}$ is illustrated in Figure 4 to explain the origin of the CBs and the highest energy of VBs. The conduction band in the range of 2.0 6.0 eV is dominated by V-3d, mixed with a small amount of Bi-6p and O-2p states. The valence band just below the Fermi level $(0.0 \mathrm{eV})$ was mainly occupied by $\mathrm{O}-2 \mathrm{p}$ and $\mathrm{V}-3 \mathrm{~d}$, with some Bi-6s and Bi-6p states' contributions. Therefore, the absorption in the UV region can be ascribed to the CT transitions from O-2p to V-3d and Bi-6p states, respectively. Combined with the optical band gap calculations, it can be argued that efficient absorption in the near UV region can exist even when the content of Bi is very low because of its occupation in the lowest conduction band of $\mathrm{YVO}_{4}$ :Bi host. 


\subsection{Influence of Particle Size}

It is also challenging to achieve good dispersion of down-conversion materials in an appropriate polymer matrix that must exhibit high transmittance to prevent scattering and absorption. The phosphor samples Sm25Na25 and Eu04 were ground into fine powders subsequently (see experimental section), and the size effect on the fluorescence performance was studied.

Figure $5 \mathrm{a}, \mathrm{b}$ shows the particle size distributions and scanning electron micrographs of Sm25Na25 phosphors. The initial size of the phosphor was about $30 \mu \mathrm{m}$ (Figure 5a). As shown in Figure $5 b$, the particle size of the phosphor was reduced, and the distribution was between $2-10 \mu \mathrm{m}$. X-ray diffraction patterns of samples with different sizes are shown in Figure 5c. The position and intensity of the XRD diffraction peaks did not change significantly, indicating that the crystal structure of the phosphors was not destroyed after ball milling. As shown in the fluorescence emission spectra of the two samples (Figure 5d), the fluorescence intensity of the large phosphor is significantly higher than that of the small one. The crystal defects that were generated during the grinding process increased the nonradiative transition channel, thereby weakening the luminescence performance of the phosphor.
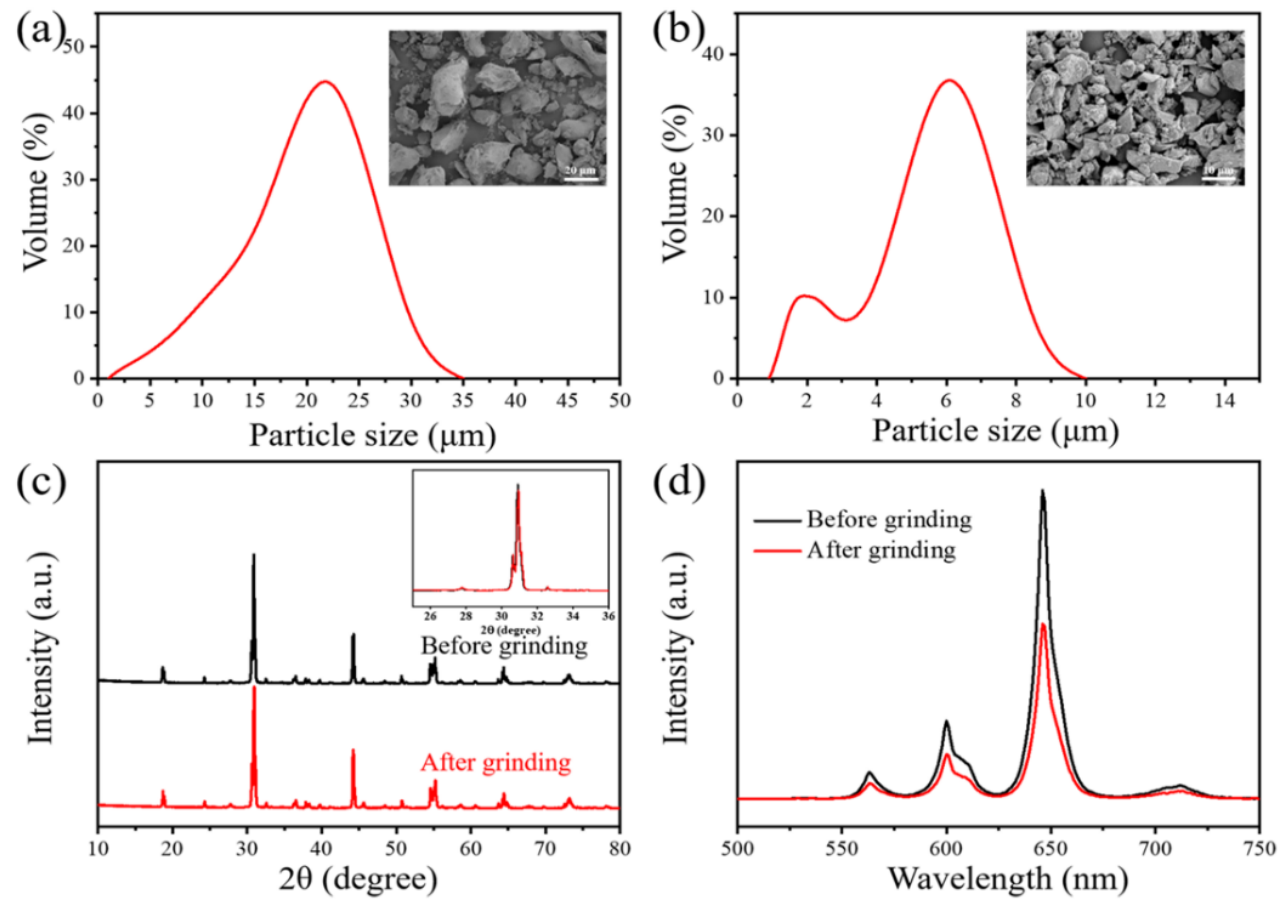

Figure 5. (a) The initial particle size distribution of Sm25Na25. (b) Particle size distribution of Sm25Na25 after grinding. (c) XRD spectra before and after grinding. (d) Emission spectra before and after grinding.

The particle size distributions and scanning electron micrographs of Eu04 are shown in Figure 6. It is evident that particles had irregular shapes and wide size distributions (Figure 6a). The particle size ranged from 1 to $14 \mu \mathrm{m}$. As shown in Figure 6b, particle size was reduced to the nanometer level, and the size distribution was mainly concentrated in 300-600 nm. The X-ray diffraction patterns and luminous performance of samples with different sizes are shown in Figure 6c,d. Similarly, the phosphors before and after ball milling had higher crystallinity, but the smaller size brought more crystal defects and reduced the fluorescence intensity. 

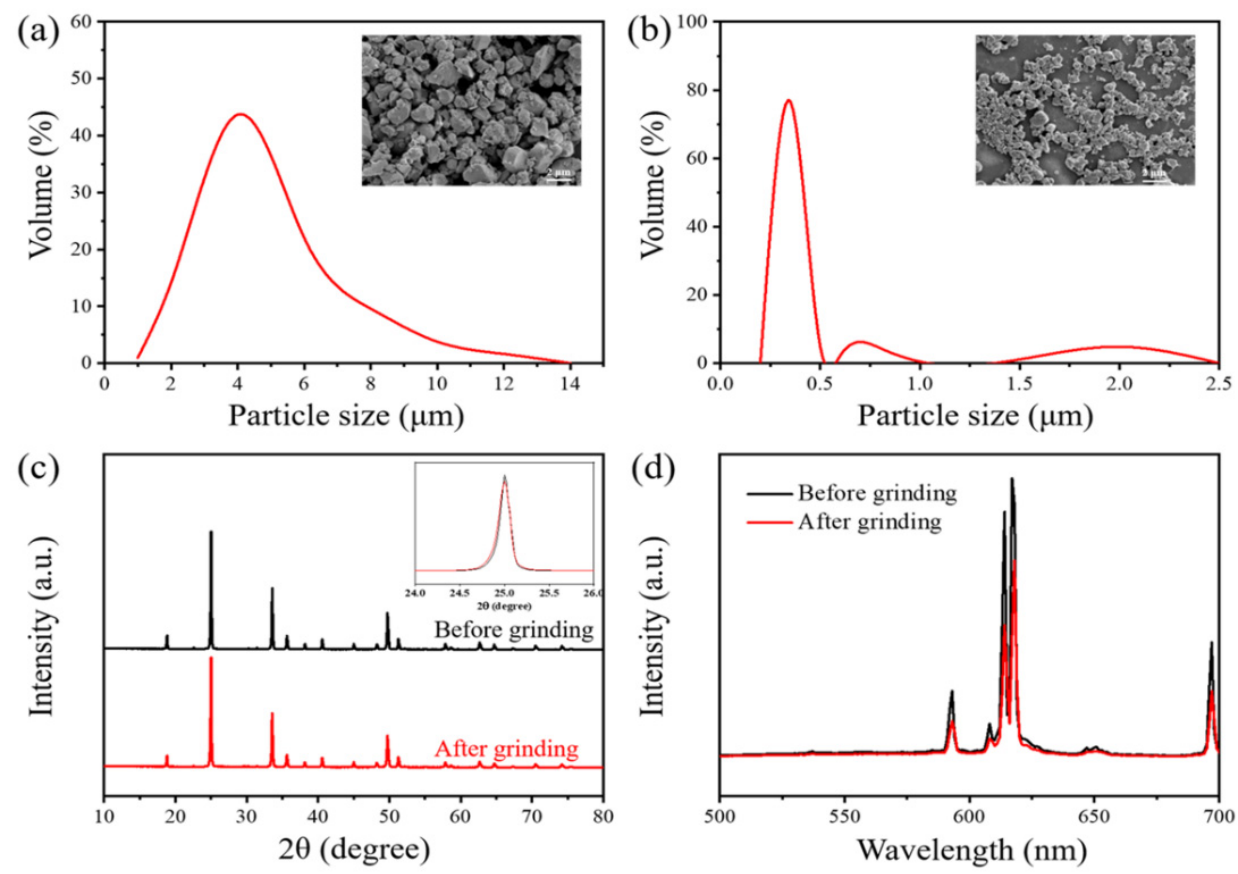

Figure 6. (a) The initial particle size distribution of Eu04. (b) Particle size distribution of Eu04 after grinding. (c) XRD spectra before and after grinding. (d) Emission spectrum before and after grinding.

\subsection{Preparations and Properties of Luminescent Polymeric Coatings}

The luminescent coatings can be obtained by dispersing luminescent materials in polymer coatings. Therefore, luminescent polymeric coatings with one single kind of phosphors were prepared. In order to broaden the absorption of the spectrum, the two phosphors were combined together in uniform polymer coatings. As far as the UV light excitation sequence was concerned, the two phosphors were assembled in bilayer coatings with different concentrations.

Figure $7 \mathrm{a}, \mathrm{b}$ shows the transmittance of PETG coatings with different phosphor concentrations $(1-4 \%)$ and coating thickness $(20$ and $30 \mu \mathrm{m})$. High transmittance $>92 \%$ can be observed in visible-infrared regions, which would hardly influence the light transmittance of the coatings. The coating transmittance was decreased as the coating thickness increased. The characteristic emission peaks were found at 562, 600, and $648 \mathrm{~nm}$ upon the excitation of $408 \mathrm{~nm}$. Photoluminescence emission (PL) spectra also showed high intensities for coatings with high phosphor concentration and coating thickness, especially the main emission peak at $648 \mathrm{~nm}$. The optical properties of $\mathrm{YVO}_{4}: \mathrm{Bi}, \mathrm{Eu}(1,2,3$ and $4 \%$ ) in PETG coatings were examined as well (Figure $7 \mathrm{c}, \mathrm{d}$ ). Similar results were also obtained. The transmittance of the composite coatings was decreased with phosphor concentration and coating thickness, while the luminescent intensity was increased. The luminescent coatings showed the $\mathrm{YVO}_{4}: \mathrm{Bi}$,Eu characteristic emission peaks at 593, 615, 618, 650 and $698 \mathrm{~nm}$ upon the excitation at $365 \mathrm{~nm}$.

The different excitation and emission wavelengths of the two phosphors enable their combination to broaden the absorption band of the UV light in the solar spectrum and achieve multipeak emission in the visible light band. Herein, the single-layer luminescent polymeric coatings that were directly mixed with two phosphors were prepared. The transmittances of coatings with two different phosphors are shown in Figure 8. High transmittance in the visible-infrared region can still be observed. The increase in coating thickness with the same phosphor concentration decreased the transmittance. The transmittance decreased as the phosphor content increased when the coating thickness was the same. Keeping the total phosphor content unchanged, the coating with more Sm25Na25 had higher transmittance than the coating with less Sm25Na25. 

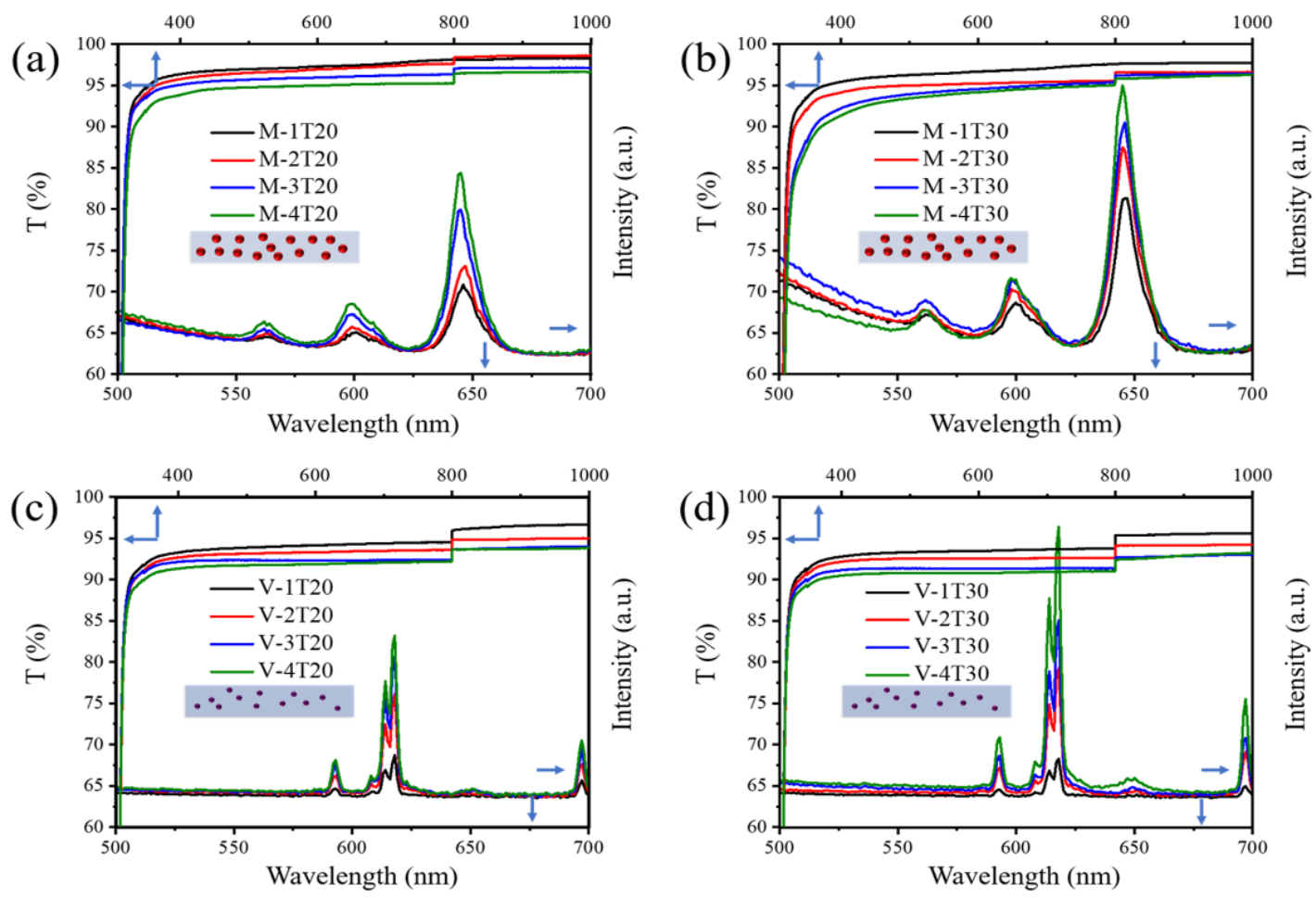

Figure 7. (a) Transmission spectra and emission spectra $\left(\lambda_{\mathrm{ex}}=408 \mathrm{~nm}\right)$ of M-1T20-M-4T20. (b) Transmission spectra and emission spectra $\left(\lambda_{\mathrm{ex}}=408 \mathrm{~nm}\right)$ of M-1T30-M-4T30. (c) Transmission spectrum and emission spectra $\left(\lambda_{\mathrm{ex}}=365 \mathrm{~nm}\right)$ of V-1T20-V-4T20. (d) Transmission spectra and emission spectra $\left(\lambda_{\mathrm{ex}}=365 \mathrm{~nm}\right)$ of V-1T30-V-4T30. (The blue arrow in the figure points to the coordinate axis corresponding to the curve).
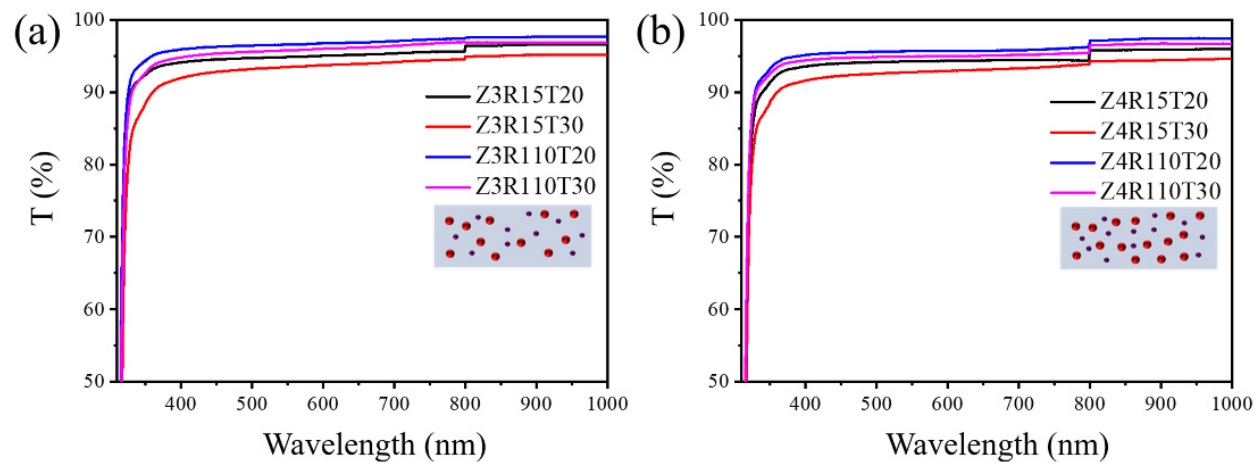

Figure 8. Transmission spectrum of the polymeric coatings that were directly mixed with two phosphors.

PL emission spectra of coatings are shown in Figure 9. The PL spectrum displayed the emissions of $\mathrm{YVO}_{4}: \mathrm{Bi}$, $\mathrm{Eu}$ and $\mathrm{Sr}_{2} \mathrm{CaMoO}_{6}: \mathrm{Sm}, \mathrm{Na}$. Upon excitation at $365 \mathrm{~nm}$, the coatings showed the characteristic emission bands of $\mathrm{Eu}^{3+}$ ions. The weak emission at $593 \mathrm{~nm}$ and the strong emission at $618 \mathrm{~nm}$ correspond to the ${ }^{5} \mathrm{D}_{1}{ }^{7} \mathrm{~F}_{1}$ and ${ }^{5} \mathrm{D}_{0}-{ }^{7} \mathrm{~F}_{\mathrm{J}}(\mathrm{J}=0-4)$ transition. The fluorescence intensity increased significantly as the powder content and coating thickness were increased. The emission at $650 \mathrm{~nm}$ excited by $365 \mathrm{~nm}$ is contributed by the two phosphors. Upon the excitation at $408 \mathrm{~nm}$, the coatings showed the weak emission at $600 \mathrm{~nm}$ and the strong emission at $648 \mathrm{~nm}$. Fluorescence intensity at $648 \mathrm{~nm}$ increased significantly with the increase in $\mathrm{Sr}_{2} \mathrm{CaMoO}_{6}: \mathrm{Sm}, \mathrm{Na}$ content. The results proved that the coatings with two phosphors should be an ideal luminescence downshifting (LDS) layer. 

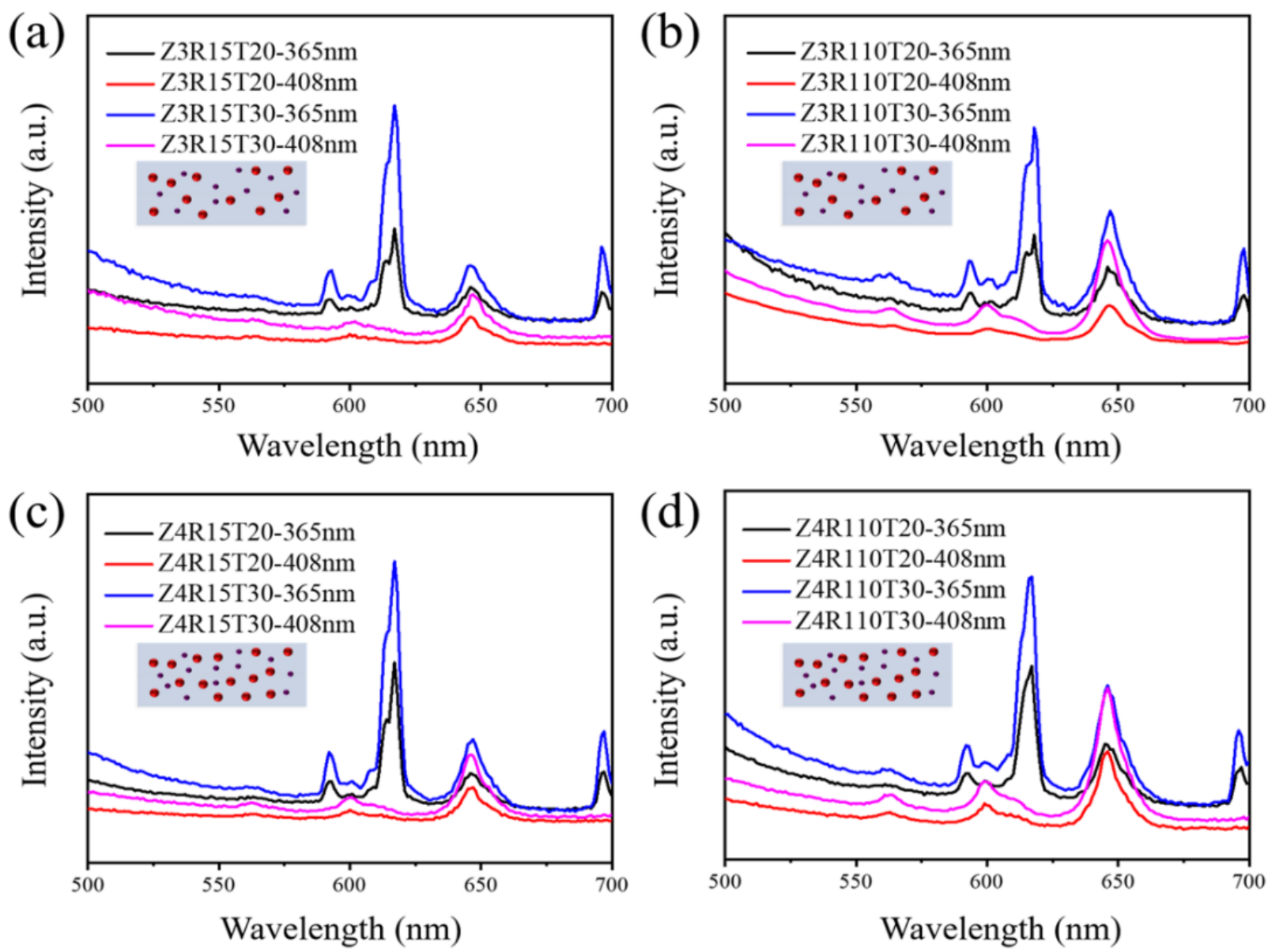

Figure 9. (a) Emission spectra of Z3R15T20 and Z3R15T30 upon the excitation at 365 and $408 \mathrm{~nm}$, respectively. (b) Emission spectra of Z3R110T20 and Z3R110T30. (c) Emission spectra of Z4R15T20 and Z4R15T30. (d) Emission spectra of Z4R110T20 and Z4R110T30.

Since vanadate and molybdate are excited by 365 and $408 \mathrm{~nm}$ photons, respectively, the penetration depth of the ultraviolet light is different. Therefore, the sequence of vanadate and molybdate may affect the fluorescence intensity of the coatings. The two phosphors were assembled in bilayer coatings with different concentrations. As shown in Figure 10a,b, high transmittance of $>92 \%$ was observed in visible-infrared regions from the transmittance spectrum. Compared with the single-layer coatings, the double-layer coatings had the same high transmittance. Figure 10c-f shows fluorescence emission spectra of the bilayer coatings. It is obvious that the coatings exhibited multiple emission peaks in the visible region. Similar to the single-layer coatings directly mixed with two phosphors, the doublelayer coatings exhibited the characteristic emission peaks of different phosphors under excitation at 365 and $408 \mathrm{~nm}$. The emission peak at $593 \mathrm{~nm}$ and $618 \mathrm{~nm}$ and the emission at $650 \mathrm{~nm}$ which were produced by the two powders together guaranteed multipeak emission. From the emission spectrum that the corresponding fluorescence intensity was higher when $\mathrm{YVO}_{4}: \mathrm{Bi}$,Eu was in the upper layer. On the contrary, when $\mathrm{Sr}_{2} \mathrm{CaMoO}_{6}: \mathrm{Sm}, \mathrm{Na}$ was in the upper layer, its corresponding emission intensity was increased. The difference in fluorescence performance controlled by layer sequence provides a way to adjust the coating's DC performance. 

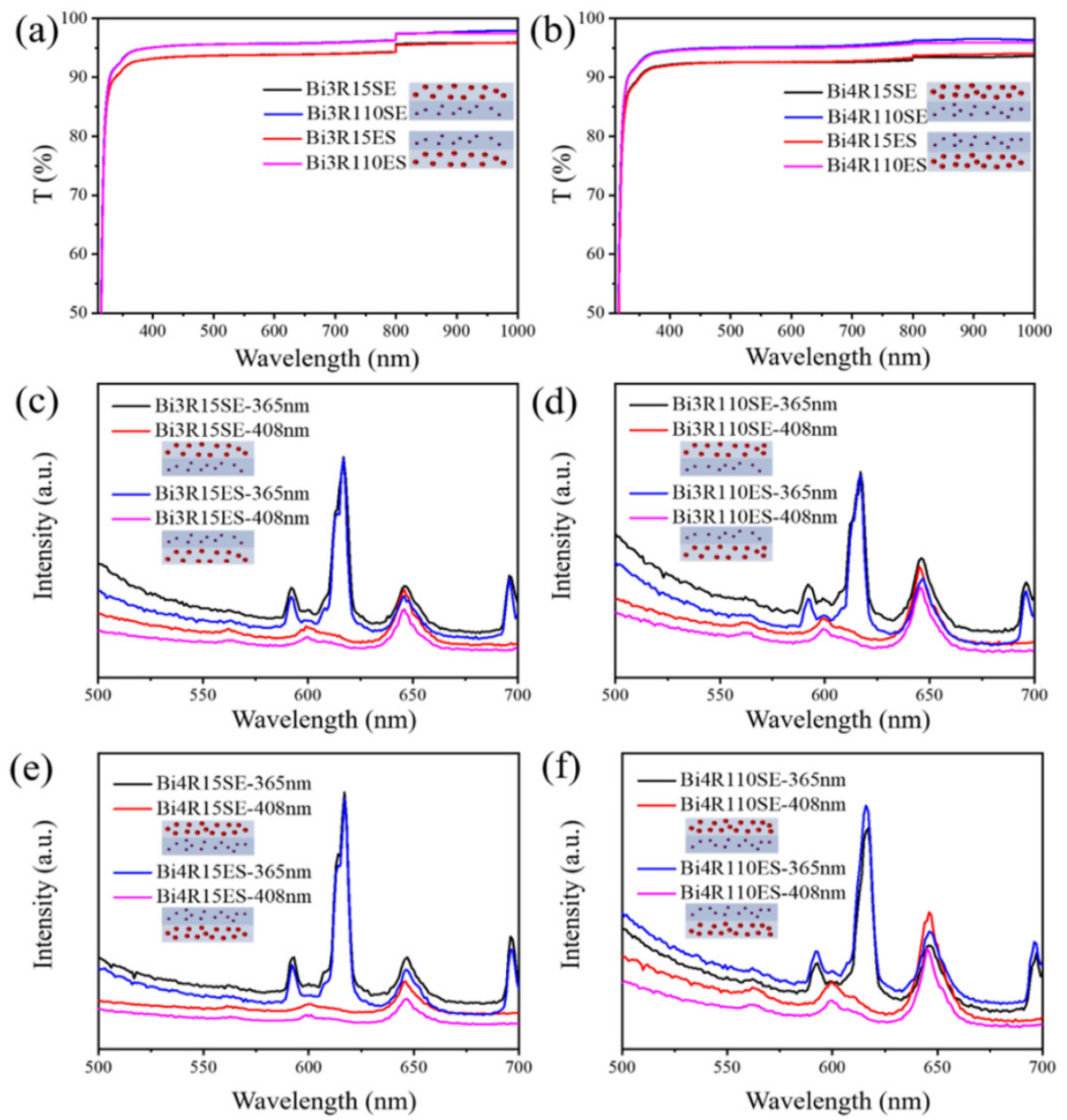

Figure 10. (a,b) Transmission spectrum of the bilayer coatings. (c) Emission spectra of Bi3R15SE and Bi3R15ES upon the excitation at 365 and $408 \mathrm{~nm}$, respectively. (d) Emission spectra of Bi3R110SE and Bi3R110ES. (e) Emission spectra of Bi4R15SE and Bi3R15ES. (f) Emission spectra of Bi4R110SE and Bi4R110ES.

\section{Conclusions}

In this paper, $\mathrm{Sr}_{2} \mathrm{CaMoO}_{6}: \mathrm{Sm}, \mathrm{Na}$ and $\mathrm{YVO}_{4}: \mathrm{Bi}$,Eu that have different excitation in the UV-blue region and varied emission peaks in the visible light regions were synthesized. $\mathrm{Sr}_{2} \mathrm{CaMoO}_{6}: \mathrm{Sm}, \mathrm{Na}$ can effectively produce red light at $648 \mathrm{~nm}$ upon the excitation at $408 \mathrm{~nm}$. The luminescent properties of $\mathrm{Sr}_{2} \mathrm{CaMoO}_{6}: \mathrm{Sm}, \mathrm{Na}$ red molybdate phosphors were improved by charge compensation. Subsequently, by changing the concentration of rare-earth ions, the absorption capacity of $\mathrm{YVO} 4: \mathrm{Bi}$, Eu red molybdate phosphor in the ultraviolet region and the luminous intensity in the visible light region were improved. $\mathrm{YVO}_{4}: \mathrm{Bi}$,Eu can effectively produce red light at $618 \mathrm{~nm}$ upon the excitation at $365 \mathrm{~nm}$. The DFT method was used to explain the chemical bonding properties and origin of CT transitions of $\mathrm{YVO}_{4}: \mathrm{Bi}$,Eu. Next, the polymeric luminescent coatings with a single phosphor were prepared. The coating's DC ability increased with the increase of phosphors concentration, and the transmittance was above $92 \%$. In order to achieve the effects of multipeak absorption and wide spectrum emission, the two phosphors were combined together in uniform polymer coatings. The coatings exhibited the characteristic fluorescence peaks of $\mathrm{Sr}_{2} \mathrm{CaMoO}_{6}: \mathrm{Sm}, \mathrm{Na}$ and $\mathrm{YVO}_{4}: \mathrm{Bi}$,Eu upon excitation at $365 \mathrm{~nm}$ and $408 \mathrm{~nm}$, respectively. The two phosphors were assembled in bilayer coatings with different concentrations, and the transparency and luminescent spectra were investigated in detail. High transmittances over $90 \%$ were achieved for the two composite coatings with the thickness of 20 and $30 \mu \mathrm{m}$. The increase in particle loadings from $1 \%$ to $4 \%$ slightly decreased film transmittance but 
increased luminescence intensity, independent of total filler loadings ( $3 \%$ and $4 \%$ ) and coating thickness. The relative intensities of emission peaks can be adjusted conveniently by changing filler ratios. Similar to the single-layer coatings directly mixed with two phosphors, the bilayer coatings have high transmittance and the characteristic emission peaks of different phosphors under excitation at 365 and $408 \mathrm{~nm}$. the transmittance and luminescent intensities of the coatings where the two phosphors were assembled in two layers were close to the uniform coatings, suggesting the negligible effect of UV light absorption order. The results proved that the coatings with multipeak absorption and multipeak emission are expected to be applied in the fields of solar cells and agricultural greenhouses.

Author Contributions: Conceptualization, C.Z. and C.L.; methodology, J.F.; software, J.F.; validation, J.F.; formal analysis, J.F. and W.L.; investigation, W.Z.; resources, Y.N.; data curation, J.F.; writing-original draft preparation, J.F. and L.F.; writing-review and editing, C.Z.; visualization, J.F.; supervision, C.L.; project administration, C.L.; funding acquisition, C.L. All authors have read and agreed to the published version of the manuscript.

Funding: This research was funded by Natural Science Foundation of Jiangsu Province, No. BK20191364, No. BK20141459.

Institutional Review Board Statement: Not applicable.

Informed Consent Statement: Not applicable.

Data Availability Statement: The data presented in this study are available in this article.

Acknowledgments: The project was also funded by the Priority Academic Program Development of the Jiangsu Higher Education Institutions (PAPD) and Jiangsu Collaborative Innovation Center for Advanced Inorganic Function Composites.

Conflicts of Interest: The authors declare that they do not at present have and do not anticipate having any conflict of interests. All authors have the authority to submit this work for publication. The manuscript or its contents in some other form have not been published previously by any of the authors and/or is not under consulting for publication in another journal at any time of the submission.

\section{References}

1. Huang, X.; Han, S.; Huang, W.; Liu, X. Enhancing solar cell efficiency: The search for luminescent materials as spectral converters. Chem. Soc. Rev. 2013, 42, 173-201. [CrossRef] [PubMed]

2. Morassaei, M.S.; Salehabadi, A.; Akbari, A.; Tavassoli, S.H.; Salavati-Niasari, M. Enhanced dye sensitized solar cells efficiency by utilization of an external layer of CaCe2(MoO4)4:Er3+/Yb3+ nanoparticles. J. Alloy Compd. 2018, 769, 732-739. [CrossRef]

3. Xiao, L.; Lai, T.; Liu, X.; Liu, F.; Russell, T.P.; Liu, Y.; Huang, F.; Peng, X.; Cao, Y. A low-bandgap dimeric porphyrin molecule for 10\% efficiency solar cells with small photon energy loss. J. Mater. Chem. A 2018, 6, 18469-18478. [CrossRef]

4. De Vos, A.; Szymanska, A.; Badescu, V. Modelling of solar cells with down-conversion of high energy photons, anti-reflection coatings and light trapping. Energy Convers. Manag. 2009, 50, 328-336. [CrossRef]

5. Richards, B.S. Luminescent layers for enhanced silicon solar cell performance: Down-conversion. Sol. Energy Mater. Sol. Cells 2006, 90, 1189-1207. [CrossRef]

6. Gunji, R.; Santos, E.A.; Bordon, C.; Garcia, J.; Gómez-Malagón, L.; Kassab, L. Germanate glass layer containing Eu ${ }^{3+}$ ions and gold nanoparticles for enhanced silicon solar cell performance. J. Lumin. 2020, 226, 117497. [CrossRef]

7. Zhang, A.; Jia, M.; Sun, Z.; Liu, G.; Fu, Z.; Sheng, T.; Li, P.; Lin, F. High concentration Eu ${ }^{3+}$-doped $\left.\mathrm{NaYb}_{(\mathrm{MoO}}\right)(2) \mathrm{multifunctional}^{2}$ material: Thermometer and plant growth lamp matching phytochrome P-R. J. Alloy Compd. 2019, 782, 203-208. [CrossRef]

8. Wu, X.; Meng, F.; Zhang, Z.; Yu, Y.; Liu, X.; Meng, J. Broadband down-conversion for silicon solar cell by ZnSe/phosphor heterostructure. Opt. Express 2014, 22, A735-A741. [CrossRef] [PubMed]

9. Wang, L.; Zhang, H.; Zhou, X.; Liu, Y.; Lei, B. A dual-emitting core-shell carbon dot-silica-phosphor composite for LED plant grow light. RSC Adv. 2017, 7, 16662-16667. [CrossRef]

10. Lin, J.; Wang, R.-Z.; Li, R.; Yan, H. A high efficient antireflective down-conversion $\mathrm{Y}_{2} \mathrm{O}_{3}: \mathrm{Bi}^{3+}, \mathrm{Yb}^{3+}$ thin films. Opt. Quantum Electron. 2017, 49, 7411. [CrossRef]

11. Wang, S.; Yao, H.; Wu, D.; Lin, Z.; Ling, Q. Highly efficient white emission from UV-driven hybrid LEDs through down-conversion of arylmaleimide-based branched polymers. J. Lumin. 2021, 230, 117742. [CrossRef]

12. Bierman, D.M.; Lenert, A.; Chan, W.R.; Bhatia, B.; Celanović, I.; Soljačić, M.; Wang, E.N. Enhanced photovoltaic energy conversion using thermally based spectral shaping. Nat. Energy 2016, 1, 16068. [CrossRef] 
13. Kumar, V.; Ntwaeaborwa, O.M.; Soga, T.; Dutta, V.; Swart, H.C. Rare earth doped zinc oxide nanophosphor powder: A future material for solid state lighting and solar cells. ACS Photonics 2017, 4, 2613-2637. [CrossRef]

14. Day, J.; Senthilarasu, S.; Mallick, T.K. Improving spectral modification for applications in solar cells: A review. Renew. Energy 2019, 132, 186-205. [CrossRef]

15. Rodriguez Burbano, D.C.; Sharma, S.K.; Dorenbos, P.; Viana, B.; Capobianco, J.A. Persistent and photostimulated red emission in $\mathrm{CaS}: \mathrm{Eu}^{2+}{ }^{2} \mathrm{Dy}^{3+}$. Nanophosphors Adv. Opt. Mater. 2015, 3, 551-557. [CrossRef]

16. Meng, L.; Wu, X.-G.; Ma, S.; Shi, L.; Zhang, M.; Wang, L.; Chen, Y.; Chen, Q.; Zhong, H. Improving the efficiency of silicon solar cells using in situ fabricated perovskite quantum dots as luminescence downshifting materials. Nanophotonics 2019, 9, 93-100. [CrossRef]

17. Zhao, L.; Shen, X.; Liu, Q.; Wu, W.; Li, H.; Chen, Z.; Li, Y. Core-shell structured layered lanthanide-organic complexes with stilbazolium-type dye encapsulation for multifunctional performances. Chem. Asian J. 2019, 15, 136-147. [CrossRef] [PubMed]

18. Zhao, L.; Xu, P.; Fan, F.; Yu, J.; Shang, Y.; Li, Y.; Huang, L.; Yu, R. Synthesis and photoluminescence properties of Sm ${ }^{3+}$ and Dy ${ }^{3+}$ ions activated double perovskite $\mathrm{Sr}_{2} \mathrm{MgTeO}_{6}$ phosphors. J. Lumin. 2019, 207, 520-525. [CrossRef]

19. Bu, F.; Shen, W.; Zhang, X.; Wang, Y.; Belfiore, L.A.; Tang, J. Hybrid ZnO electron transport layer by down conversion Complexes for dual improvements of photovoltaic and stable performances in polymer solar cells. Nanomaterials 2020, 10, 80. [CrossRef] [PubMed]

20. Cardoso, M.; Correia, S.; Frias, A.; Gonçalves, H.; Pereira, R.; Nunes, S.; Armand, M.; André, P.; Bermudez, V.D.Z.; Ferreira, R. Solar spectral conversion based on plastic films of lanthanide-doped ionosilicas for photovoltaics: Down-shifting layers and luminescent solar concentrators. J. Rare Earths 2020, 38, 531-538. [CrossRef]

21. Rahman, N.U.; Khan, W.U.; Li, W.; Khan, S.; Khan, J.; Zheng, S.; Su, T.; Zhao, J.; Aldred, M.P.; Chi, Z. Simultaneous enhancement in performance and UV-light stability of organic-inorganic perovskite solar cells using a samarium-based down conversion material. J. Mater. Chem. A 2018, 7, 322-329. [CrossRef]

22. Schmiechen, S.; Strobel, P.; Hecht, C.; Reith, T.; Siegert, M.; Schmidt, P.J.; Huppertz, P.; Wiechert, D.; Schnick, W. Nitridomagnesosilicate $\mathrm{Ba}\left[\mathrm{Mg}_{3} \mathrm{SiN}_{4}\right]: \mathrm{Eu}^{2+}$ and structure-Property relations of similar narrow-band red nitride phosphors. Chem. Mater. 2015, 27, 1780-1785. [CrossRef]

23. Watanabe, H.; Yamane, H.; Kijima, N. Crystal structure and luminescence of $\mathrm{Sr}_{0.99} \mathrm{Eu}_{0.01} \mathrm{AlSiN}_{3}$. J. Solid State Chem. 2008, 181, 1848-1852. [CrossRef]

24. Park, W.B.; Singh, S.P.; Yoon, C.; Sohn, K.-S. Combinatorial chemistry of oxynitride phosphors and discovery of a novel phosphor for use in light emitting diodes, $\mathrm{Ca}_{1.5} \mathrm{Ba}_{0.5} \mathrm{Si}_{5} \mathrm{~N}_{6} \mathrm{O}_{3}: \mathrm{Eu}^{2+}$. J. Mater. Chem. C 2013, 1, 1832-1839. [CrossRef]

25. Park, W.B.; Jeong, Y.S.; Singh, S.P.; Sohn, K.-S. A yellow-emitting oxynitride phosphor: $\mathrm{Ce}_{4-\mathrm{x}} \mathrm{CaxSi12O}_{3+\mathrm{x}} \mathrm{N}_{18-\mathrm{x}}: \mathrm{Eu}^{2+}$. ECS J. Solid State Sci. Technol. 2012, 2, R3100-R3106. [CrossRef]

26. Ding, D.; Gao, J.; Zhang, S.; Duo, L. The photoluminescence properties of $\mathrm{Pr}^{3+}-\mathrm{Yb}^{3+}$ co-doped gallo-germanate glasses and glass ceramics as energy converter. J. Lumin. 2020, 226, 117512. [CrossRef]

27. Dai, W.B.; Lei, Y.F.; Zhou, J.; Xu, M.; Chu, L.; Li, L.; Zhao, P.; Zhang, Z.H. Near-infrared quantum-cutting and long-persistent phosphor $\mathrm{Ca}_{3} \mathrm{Ga}_{2} \mathrm{Ge}_{3} \mathrm{O}_{12}: \mathrm{Pr}^{3+}, \mathrm{Yb}^{3+}$ for application in in vivo bioimaging and dye-sensitized solar cells. J. Alloy Compd. 2017, $726,230-239$.

28. de Luna, M.S.; Filippone, G. Effects of nanoparticles on the morphology of immiscible polymer blends-Challenges and opportunities. Eur. Polym. J. 2016, 79, 198-218. [CrossRef]

29. González-Pérez, S.; Sanchiz, J.; González-Díaz, B.; Holinski, S.; Borchert, D.; Hernández-Rodríguez, C.; Guerrero-Lemus, R. Luminescent polymeric film containing an Eu(III) complex acting as UV protector and down-converter for Si-based solar cells and modules. Surf. Coat. Technol. 2015, 271, 106-111. [CrossRef]

30. Fix, T.; Nonat, A.; Imbert, D.; Di Pietro, S.; Mazzanti, M.; Slaoui, A.; Charbonnière, L.J. Enhancement of silicon solar cells by downshifting with Eu and Tb coordination complexes. Prog. Photovolt. Res. Appl. 2016, 24, 1251-1260. [CrossRef]

31. Ho, W.-J.; Shen, Y.-T.; Liu, J.-J.; You, B.-J.; Ho, C.-H. Enhancing photovoltaic performance using broadband luminescent downshifting by combining multiple species of Eu-doped silicate phosphors. Nanomaterials 2017, 7, 340. [CrossRef]

32. Song, H.; Wang, J.; Chen, B.; Peng, H.; Lu, S. Size-dependent electronic transition rates in cubic nanocrystalline europium doped yttria. Chem. Phys. Lett. 2003, 376, 1-5. [CrossRef]

33. Chen, H.-Y.; Chang, C.-W. Solvatochromism study of DCM encapsulated in ZIF-90 and the potential application of DCM/ZIF-90 as the fluorescence down-conversion layer for an LED chip. J. Phys. Chem. C 2020, 124, 8854-8860. [CrossRef]

34. Xu, W.; Zhu, Y.; Chen, X.; Wang, J.; Tao, L.; Xu, S.; Liu, T.; Song, H. A novel strategy for improving upconversion luminescence of $\mathrm{NaYF}_{4}: \mathrm{Yb}$, Er nanocrystals by coupling with hybrids of silver plasmon nanostructures and poly(methyl methacrylate) photonic crystals. Nano Res. 2013, 6, 795-807. [CrossRef]

35. Zhang, X.; Li, B.; Jiang, M.; Zhang, L.; Ma, H. Core-spacer-shell structured $\mathrm{NaGdF}_{4}: \mathrm{Yb}^{3+} / \mathrm{Er}^{3+} @ \mathrm{NaGdF}_{4} @ \mathrm{Ag}$ nanoparticles for plasmon-enhanced upconversion luminescence. RSC Adv. 2016, 6, 36528-36533. [CrossRef]

36. Podhorodecki, A.; Banski, M.; Noculak, A.; Sojka, B.; Pawlik, G.; Misiewicz, J. On the nature of carrier relaxation and ion-ion interactions in ultrasmall beta-NaYF $4: \mathrm{Eu}^{3+}$ nanocrystals-Effect of the surface. Nanoscale 2013, 5, 429-436. [CrossRef]

37. Maurya, A.; Bahadur, A.; Rai, S. Enhanced red emission from $\mathrm{Eu}^{3+}, \mathrm{A}^{+}\left(\mathrm{Li}^{+}, \mathrm{Na}^{+}, \mathrm{K}^{+}\right)$co-doped CaZrO 3 phosphor. J. Lumin. 2018, 203, 714-722. [CrossRef]

38. Liu, S.; Liang, Y.; Zhu, Y.; Li, H.; Chen, J.; Wang, M.; Li, W. Enhancing emission intensity and thermal stability by charge compensation in $\mathrm{Sr}_{2} \mathrm{Mg}_{3} \mathrm{P}_{4} \mathrm{O}_{15}: \mathrm{Eu}^{3+}$. J. Am. Ceram. Soc. 2017, 101, 1655-1664. [CrossRef] 
39. Puchalska, M. High enhancement of $\mathrm{Eu}^{3+}$ luminescence in $\mathrm{SrAl}_{4} \mathrm{O}_{7}$ phosphor by means of charge compensation with $\mathrm{Na}^{+}$ions. Opt. Mater. 2017, 72, 452-458. [CrossRef]

40. Zhang, Z.; Han, C.-L.; Shi, W.-W.; Kang, Y.-Y.; Wang, Y.-S.; Zhang, W.-G.; Wang, D.-J. Enhanced novel white emission in Ca $3\left(\mathrm{PO}_{4}\right)_{2}: \mathrm{Dy}^{3+}$ single-phase full-color phosphor by charge compensation. J. Mater. Sci. Mater. Electron. 2014, 26, 1923-1931. [CrossRef]

41. Ding, X.; Zhu, G.; Geng, W.; Wang, Q.; Wang, Y. Rare-earth-free high-efficiency narrow-band red-emitting $\mathrm{Mg}_{3} \mathrm{Ga}_{2} \mathrm{GeO}_{8}: \mathrm{Mn}^{4+}$ phosphor excited by near-UV light for white-light-emitting diodes. Inorg. Chem. 2016, 55, 154-162. [CrossRef]

42. Huang, H.; Li, H.; Wang, Z.; Wang, P.; Zheng, Z.; Liu, Y.; Dai, Y.; Li, Y.; Huang, B. Efficient near-infrared photocatalysts based on $\mathrm{NaYF}_{4}: \mathrm{Yb}^{3+}, \mathrm{Tm}^{3+} @ \mathrm{NaYF}_{4}: \mathrm{Yb}^{3+}, \mathrm{Nd}^{3+} @ \mathrm{TiO}_{2}$ core@shell nanoparticles. Chem. Eng. J. 2019, 361, 1089-1097. [CrossRef]

43. Zhang, L.; Sun, B.; Shao, C.; Zhen, F.; Wei, S.; Bu, W.; Yao, Q.; Jiang, Z.; Chen, H. Preparation, band-structure and luminescence of double perovskite $\mathrm{Ba}_{2} \mathrm{MgMoO}_{6}: \mathrm{Eu}^{3+}$ orange-red phosphor for white LEDs. Ceram. Int. 2018, 44, 17305-17312. [CrossRef]

44. Wang, L.; Noh, H.M.; Moon, B.K.; Park, S.H.; Kim, K.H.; Shi, J.; Jeong, J.H. Dual-mode luminescence with broad near UV and blue excitation band from $\mathrm{Sr}_{2} \mathrm{CaMoO}_{6}: \mathrm{Sm}^{3+}$ phosphor for white LEDs. J. Phys. Chem. C 2015, 119, 15517-15525. [CrossRef]

45. Li, Q.; Dong, J.; Wang, Q.; Xue, Y.; Tang, H.; Xu, X.; Xu, J. Crystal growth, spectroscopic characteristics, and Judd-Ofelt analysis of Tm:GdScO 3 . Opt. Mater. 2020, 109, 110298. [CrossRef]

46. Liu, J.; Wang, K.; Zheng, W.; Huang, W.; Li, C.-H.; You, X.-Z. Improving spectral response of monocrystalline silicon photovoltaic modules using high efficient luminescent down-shifting Eu ${ }^{3+}$ complexes. Prog. Photovolt. Res. Appl. 2012, 21, 668-675. [CrossRef]

47. Wang, L.; Noh, H.M.; Moon, B.K.; Choi, B.C.; Jeong, J.H.; Shi, J. Luminescent properties and energy transfer of Sm ${ }^{3+}$ doped $\mathrm{Sr}_{2} \mathrm{CaMo}_{1-\mathrm{x}} \mathrm{W}_{\mathrm{x}} \mathrm{O}_{6}$ as a potential phosphor for white LEDs. J. Alloy Compd. 2016, 663, 808-817. [CrossRef] 